NBER WORKING PAPER SERIES

\title{
WHY DOES FINANCIAL DEVELOPMENT MATTER? THE UNITED STATES FROM 1900 TO 1940
}

\author{
Rajeev Dehejia \\ Adriana Lleras-Muney \\ Working Paper 9551 \\ http://www.nber.org/papers/w9551 \\ NATIONAL BUREAU OF ECONOMIC RESEARCH \\ 1050 Massachusetts Avenue \\ Cambridge, MA 02138 \\ March 2003
}

The authors are grateful to Ben Bernanke, Charles Calomiris, William Collins, David Cutler, Angus Deaton, Esther Duflo, Claudia Goldin, Christina Paxson, Hélène Rey, and Cecilia Rouse for invaluable conversations and comments and to workshop participants at Columbia University, The World Bank, the Federal Reserve Bank of Philadelphia, the NEUDC Conference, the London School of Economics, University College London, and Princeton University for their suggestions. Dehejia thanks the National Bureau of Economic Research and the Industrial Relations Section, Princeton University, for their hospitality while working on this project. The views expressed herein are those of the authors and not necessarily those of the National Bureau of Economic Research.

(O2003 by Rajeev Dehejia and Adriana Lleras-Muney. All rights reserved. Short sections of text not to exceed two paragraphs, may be quoted without explicit permission provided that full credit including Onotice, is given to the source. 
Why Does Financial Development Matter? The United States from 1900 to 1940

Rajeev Dehejia and Adriana Lleras-Muney

NBER Working Paper No. 9551

March 2003, Revised June 2006

JEL No. E5, J82, N1, N2, O16

\begin{abstract}
$\underline{\text { ABSTRACT }}$
There is a substantial literature arguing that financial development contributes to economic growth. In this paper, we contribute to this literature by examining the effect of state-level banking regulation on financial development and economic growth in the United States from 1900 to 1940. Specifically, we make three contributions. First, drawing on the banking history literature, we carefully control for factors that could confound a causal interpretation of the effect of financial development on growth. Second, drawing on available data for this period, we examine the pathways through which financial development can affect growth; in particular, we examine the impact of these laws on a range of farm, manufacturing, and human capital outcomes. Third, we document that not all forms of financial development have a positive effect on economic growth. In particular indiscriminate lending can negatively impact economic growth.
\end{abstract}

Rajeev Dehejia

Department of Economics and SIPA

Columbia University

420 West $118^{\text {th }}$ Street, Room 1022

New York, NY 10027

and NBER

rd247@columbia.edu
Adriana Lleras-Muney

Department of Economics and

Woodrow Wilson School

Princeton University

320 Wallace Hall

Princeton, NJ 08544

and NBER

alleras@princeton.edu 


\section{Introduction}

This paper studies the effect of state-level banking regulation on financial development and on components of state-level growth in the United States from 1900 to 1940. We use these banking laws to assess the findings of a large recent literature that has argued that financial development contributes to economic growth. We contend that the institutional mechanism leading to financial development is important in determining its consequences and that some types of financial development can even retard economic growth. For the United States from 1900 to 1940 , we argue that the financial expansion induced by bank branching accelerated the mechanization of agriculture, spurred growth in manufacturing and decreased child labor. By contrast, financial expansions induced by state deposit insurance had negative consequences for the agricultural and manufacturing sectors.

Several recent papers (e.g. Beck, Levine, and Loyza [2000]; Guiso, Sapienza, and Zingales [2004]; Jayaratne and Strahan [1996]; King and Levine [1993]; Levine and Zervos [1998]; and Rajan and Zingales [1998]) have established a persuasive link between the size of the financial sector and growth. We view our focus on institutions leading to financial development and on pathways of growth as a natural next step. The economic history literature and a few recent papers (Kroszner, Laeven, and Klingebiel [2005] and Dell'Ariccia, Detragiache, and Rajan [2005]), ${ }^{1}$ and indeed contemporary experience in the United States (with the Savings and Loan Crisis) and in East Asia, suggest that not all forms of financial expansion contribute to growth. Our empirical work provides a rich framework within which to examine this claim. ${ }^{2}$

The United States from 1900 to 1940 provides an ideal setting in which to examine this issue. During this period, state banks constituted a large fraction of all financial intermediaries. As White (1997) observes: "In 1900 commercial banks held approximately two-thirds of the assets of all financial intermediaries ... today commercial banks hold less than one third of these assets." There were two significant sources of variation in banking

\footnotetext{
${ }^{1}$ See Gurley and Shaw (1960), Cameron (1967), Goldsmith (1969), McKinnon (1973), Shaw (1973), Rousseau and Wachtel (1998), and Sylla (1969, 1972, 2002), and the discussion in Mehrling (1997). Kroszner, Laeven, and Klingebiel (2005) examine the effect of financial crises on industries with differing degrees of financial dependence. Using data from 36 countries, they show significant negative effects on growth. Using a panel of 41 countries, Dell'Ariccia, Detragiache, and Rajan (2005) show that financially dependent industries experience slower growth during banking crises than less financially dependent industries.

${ }^{2}$ Our work is also related to the recent literature on the role of institutions in economic development, which includes papers such as Acemoglu, Johnson, and Robinson (2000, 2001, 2002), who examine the role of colonial institutions in determining subsequent patterns of growth and use differences in mortality rates among European settlers as an instrument for institutions; Djankov, Glaeser, La Porta, Lopez-de-Silanes, and Schleifer (2003), who look at the choice of institutions and the tradeoff between disorder and dictatorship; Botero, Djankov, La Porta, Lopez-de-Silanes, and Schleifer (2003), who study institutions regulating the
} 
regulation across states at the time - state-bank branching and state deposit insurance - and these generated considerable variation both between and within states. There were 54 changes in branching and 16 changes in state deposit insurance (see Table 1). Interestingly, economic theory predicts that branching has an unambiguously positive effect on credit and thus on growth, whereas deposit insurance does not: deposit insurance can reduce banks' cost of lending and increase credit, but it also creates a moral hazard problem by reducing the cost of making risky loans. Since deposit insurance was implemented in agricultural states and state banks were involved with agricultural loans, the expansion of credit during the agricultural boom of World War I and the contraction of credit during the subsequent agricultural crisis (see also Calomiris [1992], Wheelock [1992], and Wheelock and Kumbhaker [1995]) allow us to examine both effects.

In this paper, we first consider why some states adopted branching and deposit insurance laws. Several theories have been proposed (see Calomiris [1992, 2000]; Kroszner [1998]; Wheelock [1992]; Wheelock and Kumbhakar [1995]; Wheelock and Wilson [1995]; White [1981, 1982, 1983]; and Kroszner and Strahan [1999] on more recent changes in banking regulation), but the literature so far has considered each of these theories independently. One of the contributions of this paper is that it examines the relative merits of these theories using a single and more comprehensive data set. We find that a relatively large state banking sector is significantly associated with branching and deposit insurance, and that states with large manufacturing establishments were more likely to adopt branching. We find some evidence that banking regulation responds to crises or downturns in a state. Unlike previous work, we find no evidence that the size of state banks mattered, or that the size of farms mattered. We also find that the party composition of the state legislature had no effect on the type of laws a state passed.

We go on to examine the effect of deposit insurance and branching on a range of farming, manufacturing, and child labor outcomes, as well as estimates of personal income at the state level. We pay particular attention to the issue of causality using a range of strategies. First, we include time and year fixed effects. Second, we take advantage of the agricultural crisis which was an exogenous negative shock that affected agricultural production in all states. Third, we test whether our results are robust to controlling for possible sources of self-selection and endogeneity, in particular controlling for those variables that in our analysis emerge as important in accounting for selection into labor market; and Djankov, La Porta, Lopez-de-Silanes, and Schleifer (2003), who examine consequences of 
branching and deposit insurance. Finally, we use the activity of national banks located in each state to control for state-specific economic shocks.

Our results yield insights into how financial development matters. Regulation that lowers the cost of lending, such as branching, has an unequivocally positive effect on economic performance. On the other hand, the results for deposit insurance suggest that regulation that encourages lending without concern for the quality of loans can have a detrimental effect on growth. In particular, we show that financial development through branching contributed to a consolidation of the farming sector (in terms of fewer and more intensively cultivated farms) and an expansion of manufacturing activity. In contrast, deposit insurance led to a decrease in agricultural and manufacturing output.

This paper is organized as follows: Section 2 provides a framework for thinking about the effect of branching and deposit insurance laws. Section 3 presents our empirical strategy and a data description. Section 4 examines the political economy process that resulted in the passage of these regulations. Section 5 presents our main results. Section 6 presents specification checks and extensions. Section 7 discusses the plausibility of our results, and Section 8 concludes.

\section{Institutions and Financial Development}

This section describes the banking laws that we study, and the anticipated impact of these laws on financial development. Banking in the United States has been regulated at both the state and the federal level since the National Banking Act of 1864. Banks incorporate either as state or national banks and therefore are subject to different regulations governing, for example, their reserve ratios, minimum capital requirements, and portfolio of loans. In this paper we concentrate on two areas of state bank regulation: branching and deposit insurance.

Branching laws allow banks to establish multiple offices within a state. National banks were largely prohibited from branching until the Glass-Steagall Act of 1933, which permitted national banks to branch within states that allowed state banks to branch (Bradford [1940, p. 20]). ${ }^{3}$ States were free to set branching regulations for state banks. At

\footnotetext{
legal institutions.

${ }^{3}$ This prohibition was weakened on three occasions. In 1918, the Consolidation Act allowed national banks that merged with state banks to retain their branches (Bradford [1940, p. 10]; White [1983, p. 161]). In 1923, national banks were allowed to establish "additional offices" for the purpose of receiving deposits and cashing checks (Westerfield [1931, p. 24]). In 1927 the McFadden Act allowed state banks to retain their branches if they joined the Federal Reserve System (Bradford [1940 p. 15]; White [1983 p. 164]). The
} 
the beginning of our sample period, branching was permitted in 17 states. Economists have long advocated the benefits of branching. Sprague (1902, cited in White [1981]) argued that branching provides a form of insurance for banks: by operating across different geographic locations, a bank can diversify the risk from idiosyncratic local shocks. Calomiris (1992, p. 302) documents that state banking systems that allowed branching were effectively able to withstand a wide range of shocks. Branching also allows banks to exploit economies of scale in banking services. Finally, it can be argued that branching increases the efficiency of banks by facilitating entry. See for example Jayaratne and Strahan (1998). Therefore, all else equal, the predicted effect of branching is increased credit availability, and this in turn will contribute to economic growth.

Deposit insurance laws insure depositors in case of bank default. Banks contribute to a fund that protects deposits and also can extend credit to the bank. Whether deposit insurance is desirable is a subject of much debate in economics. Deposit insurance creates a strong moral hazard problem (see White [1983], Wheelock [1992], Wheelock and Kumbhakar [1995] and Wheelock and Wilson [1995]). The same moral hazard problem exists for all "lenders of last resort," and has been discussed extensively in terms of the role of the Federal Reserve and of other lending institutions, including the International Monetary Fund (Fischer [1999]). The evidence presented in Calomiris (1992) suggests that banks in states with deposit insurance extended credit indiscriminately, therefore experiencing relatively large expansions in credit and economic activity in times of economic growth but also sharper declines in credit and growth in times of recession. In particular, state banks (which were primarily rural) made risky loans tied to agriculture during the agricultural boom. When agricultural prices where high, the risk paid off, but after the collapse of agricultural prices (and with the erosion of land values) these loans were no longer viable. ${ }^{4}$ The agricultural boom prior to 1920 and the crisis that followed allow us to test this prediction empirically.

McFadden Act also allowed national banks to open branches in their home-city offices if state regulations allowed branching.

${ }^{4}$ This mechanism is observed in other settings as well. For example, deposit insurance exacerbated the difficulties of Savings and Loans in the 1980s. The sharp run up in interest rates in the early 1980s pushed many S\&Ls into difficulty. But rather than being dissolved, many of these institutions further increased the riskiness of their portfolio; with downside risk covered by deposit insurance, they faced only the upside benefits. Examples of risky investments include real estate and junk bonds. These risky investments ceased to be viable in the face of sharp economic downturns and an erosion in the price of oil. See Bentson and Kaufman (1997), Brewer and Mondschean (1994), White (1993), and Akerlof, Romer, Hall, and Mankiw (1993). 
Table 1 presents a snapshot of branching and deposit insurance laws from 1900 to 1940 in the 48 states. These laws were collected from several data sources - but ultimately we were able to determine the laws that were in place in every state for every year of our study. (See Appendix A for additional details.) In any given year, states fall into three categories: states with deposit insurance, states with branching, and states with neither. With the exception of a few years of overlap in Mississippi and Washington, deposit insurance and branching generally were seen as mutually exclusive options. Further note that there is a sufficient amount of variation over time to allow us to identify the effects of these laws, even after controlling for state and year fixed effects. Over the entire period we observe 16 changes in insurance laws (eight states - Iowa, Mississippi, Nebraska, North Dakota, Oklahoma, South Dakota, Texas, and Washington - adopted and eventually repealed deposit insurance) and 54 changes in branching laws. As Figure 1 suggests, these changes were not always in the same direction. We do not analyze the period after 1940 for two reasons. First, (see Figure 1) there is little variation in the laws after the mid-1930s, up until the period of deregulation in the 1970s. Second, many of the changes in banking subsequent to the Depression changed the environment in which banks operate (see the discussion below).

\section{Empirical Strategy and Data Description}

\subsection{Empirical Strategy}

Our overall objective is to examine the effect of financial development on economic growth. We pursue this objective by examining the effect of branching and deposit insurance regulation. We first confirm that these laws contributed to financial development in the state banking sector. We then investigate whether the laws had an impact on various components of economic growth. In particular, we estimate the following:

$$
\text { Outcome }_{s y}=\beta_{1} \text { Insurance }_{s y}+\beta_{2} \text { Insurance* }^{*}(\text { year }>1920)_{s y}+\beta_{3} \text { Branching }_{s y}+\gamma X_{s y}+\mathrm{e}_{s y}
$$

where $s$ refers to state, $y$ to year, and $X$ is a set of controls, including state and year fixed effects. ${ }^{5}$ Therefore the effects of these laws are identified by changes within states over

\footnotetext{
${ }^{5}$ An issue to consider is why we do not use these policy changes as instruments for an endogenous variable, such as the growth rate of loans. In the present analysis, this would not be appropriate: even though the laws appear to be exogenous, their effect does not necessarily operate exclusively through any one variable such as the growth rate of loans or deposits. In the terminology of Angrist, Imbens, and Rubin (1996), branching and
} 
time. We weight these regressions using state population. ${ }^{6}$ Since potentially there is serial correlation in these laws, the errors in all estimations are clustered at the state level, as suggested by Bertrand, Duflo, and Mullainathan (2002).

The first outcome of interest is the growth rate of loans of state banks, which measures the credit activity of state banks. Our coefficients of interest are $\beta_{1}, \beta_{2}$, and $\beta_{3}$. We predict that $\beta_{1}>0, \beta_{2}<0$, and $\beta_{3}>0$. Given the discussion in Section 2 , we believe that branching leads to an increase in banking activity, as does deposit insurance in a growing economy, and that states with deposit insurance experience more rapid declines in bank activity during a downturn. After confirming this pattern of effects on bank activity, we examine whether these laws induce a similar pattern of effects on outcomes that measure components of growth.

Before proceeding, we consider an important issue: under what circumstances can these coefficients be thought of as causal? There are two factors that could confound a causal interpretation: which states adopted these laws, and whether they would have performed equally well (or poorly) in the absence of regulation. Both of these are related to the question of why these laws were adopted by states. Thus in Section 4 we investigate what is known about the historical and political context in which these regulations were adopted. In particular, the answer will determine which set of controls we should include, and which types of sensitivity analyses we can conduct in order to lend credence to a causal interpretation of our results.

\subsection{Data Description}

Table 2 presents descriptive statistics for our data. All values are expressed in 1947-1949 dollars. $^{7}$ Data on banking outcomes exist for all years between 1900 and 1940 at the state level, for both state and national banks, including loans, deposits, assets, and capital. During this period, the majority of banks (about 70 percent) were state banks, and these banks were economically more important: on average state banks accounted for three-fifths of total loans in a state and they had higher capital-to-asset ratios than national banks.

deposit insurance laws may satisfy the exogeneity assumption, but not the exclusion restriction assumption. The effects we measure are therefore reduced form and capture the causal effects of the laws through a variety of channels.

${ }^{6}$ The results are not very sensitive to the use of weights. We choose to weight the regressions since many of our outcomes are means.

${ }^{7}$ We use the series on wholesales prices compiled by the Bureau of Labor Statistics and available in the Historical Statistics of the United States. We also experimented with using the CPI, which yielded very similar results but is only available starting in 1914 and would have to be extrapolated for the earlier period. 
Overall, banks grew during this period (as evident in Figure 2), but annual growth rates varied substantially. Additional data on the number of banks with branches and the number of branches is available for some years during this period. For the years for which branch data are available, there were about 177 banks per million residents and 4 banks with branches per million residents (with an average of 2.5 branches per bank).

To the extent possible, we gather information on any economic activity and outcomes that could be affected by credit expansions. We collect data on agriculture and manufacturing as well as on child labor. Although no data exist on state-by-year GDP or income, we use estimates of state-level personal income from a variety of sources (see data appendix). ${ }^{8}$

Data on agricultural activity come from several sources (see data appendix) and are available every five or ten years depending on the source and the variable. For each state, we know the number of acres devoted to agriculture and the number of farms. Although information does not exist for all input costs, we have data on the value of machinery, the main capital input. Profits are not known but we have two proxies for them: the value of crops and the value of cash receipts. Unfortunately, these last two outcomes are available for very few years. Data on manufacturing activity (employment, wages, and per capita value added) comes from the Census of Manufactures and are available every two years starting in 1919 and every five years prior to that.

From the censuses (every ten years), we calculate the percentage of children ages 10 to 15 who were not in school and also report being at work; we consider this to be a measure of child labor. ${ }^{9}$ On average, we observe about six percent of male children working, twice as many as girls, but there is substantial variation in the extent of child labor, from zero to about 37 percent. We also obtain population and percent urban, which we interpolate between censuses.

Estimates of personal income by state are available for 1900, 1919, 1920, 1921, and from 1929 onward. We use nominal-dollar estimates, and deflate them using the Wholesale

\footnotetext{
${ }^{8}$ We do not examine the effect of these regulations on home ownership. The reason is that in this period housing finance was not facilitated primarily by banks. National banks were prohibited or severely limited from participating in this market. State banks could make real estate loans, but these constituted less than 20 percent of their portfolio. Furthermore, most real estate loans were for the purchase of land rather than homes (see Carter [1992], Chapter 3), and those mortgages that were offered were usually for less than five years. Therefore, we are not surprised that when we look at this outcome, using data from the census, we find small and mostly insignificant results.

${ }^{9}$ This is a similar definition to the one that is used by the ILO to measure child labor for developing countries today (see Dehejia and Gatti [2002]). This definition also captures the majority of working children. The ILO
} 
Price Index. We divide by the (estimated) state population to obtain per capita income. On average, per capita income was about $\$ 577$ (in 1947-1949 dollars) for the years for which data are available.

Finally, we obtain data on the political affiliation of state legislatures (upper and lower houses) and governors for every year in the period. For each election year, we know the party of the elected governor and of the members of the legislature.

\section{The Political Economy of Branching and Deposit Insurance}

In this section we outline a range of theories that account for the passage of deposit insurance and branching laws. For each theory, we identify a set of variables that allows us to examine the postulated effect, and then we test the significance of these variables in predicting passage of the laws.

\subsection{Historical View}

The literature on banking history suggests that state banks were divided into two camps: small, rural, unit banks ${ }^{10}$ that opposed branching and promoted deposit insurance; and large, typically urban banks that did the opposite. The balance between these two groups, it is argued, ultimately determined state regulation.

One of the weaknesses of a unit banking system, especially in the context of a predominantly agricultural economy, was its susceptibility to local shocks. Shortages of liquidity in reserve centers (such as Boston, St. Louis, Chicago, and New York) or unanticipated demands for liquidity from country banks could have effects that cascaded through the banking system, see White (1983, pp. 65ff.). The 1907 bank panic was one such crisis, ${ }^{11}$ and it reinvigorated an ongoing debate on reforming the banking system. After the 1907 panic, deposit insurance and branching were proposed as means of preventing future crises. Indeed, Figure 1 suggests an upswing in both branching and deposit insurance regulation following the banking crisis. At the time, these two policies were seen as mutually exclusive alternatives.

estimates that there are 78.5 million children under 15 years of age working today (estimated using data from 124 countries), 70.9 million of them are between 10 and 14 years old.

${ }^{10}$ Unit banks refer to one-roof banks that do not have any branches or offices.

${ }^{11}$ In 1907 a seasonal upswing in the demand for liquidity was preceded by an increase in the discount rate of European central banks, and coincided with a downturn in the business cycle. The combination of the three events led to a sharp decrease in liquidity available in reserve cities and eventually to a widespread bank panic (see White [1983, pp. 74-83]; Calomiris [1992]). 
White (1982; 1983, pp.156ff) and Economides, Hubbard, and Palia (1996) argue that opposition to branching was due to the rent-preserving behavior of small, country banks. These banks essentially functioned as local monopolists. Given the (small) size of the local market, entry by a new bank - which would have to meet state or federal capital requirements - was difficult. If branching were permitted, then a bank could enter the market and open a new branch without having to satisfy the capital requirements for that location. On the other hand, large urban banks favored branching, since it would allow them to expand within and beyond the urban centers in which they operated. Given their (larger) size, they could offer banking services to smaller communities, and compete with unit banks. $^{12}$

The same lobby that opposed branching favored the adoption of deposit insurance, which offered unit banks protection against short-term, local shocks in the demand for liquidity. Thus, in relatively agricultural states where the economy was dependent on one or two commodities, there was a strong lobby for state deposit insurance schemes. Iowa, Mississippi, Nebraska, North Dakota, Oklahoma, South Dakota, Texas, and Washington eventually adopted such schemes. On the other hand, city bankers were strongly opposed to deposit insurance: they believed that deposit insurance would establish a system whereby large banks subsidized small banks in economic downturns (White [1981, 1982]). Thus, in more urban states branching, not deposit insurance, was favored by legislators. ${ }^{13}$

The historical account we have just outlined suggests that larger, more urban states would favor branching; we examine this by looking at the effect of population and percent urban population by state. The discussion also suggests that states with smaller, more fragmented state banks would oppose branching and favor deposit insurance. We examine

\footnotetext{
${ }^{12}$ Indeed, large banks - led by A. P. Giannini (see White [1982]) - actively lobbied for branching. State bankers' associations, which existed in many states (e.g. Kansas, Illinois, Iowa, Minnesota, Nebraska, and South Dakota) and were often controlled by unit bankers, argued that branching was undesirable because it would lead to a banking system dominated by a few large urban banks, thereby making it more difficult for (rural and small) depositors to acquire information about a bank's operation. See for example Chapman and Westerfield (1942, p. 8). As a consequence, even though unit bankers constituted a small share of the banking industry in economic terms, often their views were supported by the public at large and by state legislators. For example, in a 1924 referendum, voters in Illinois rejected branching by a large majority. See White (1982).

${ }^{13}$ The second incarnation of deposit insurance came in 1935, through the Federal Deposit Insurance Corporation, a creation of the Banking Act. Though it is of great importance to the post-war history of banking, federal deposit insurance is of limited importance to this paper: it was established late in the sample period, and it was a "treatment" applied to the entire country. Thus, its effects are washed out in betweenstate comparisons. Non-member (i.e., state) banks were reluctant to join the Temporary Deposit Insurance Fund, because they could receive insurance only if they agreed to join the Federal Reserve System. Under the Banking Act of 1935, this provision was reversed, with non-members permitted to join subject to the approval of the FDIC. By 1935, 91 percent of commercials banks had joined the system. See White (1983).
} 
this through the average deposits per state bank (our proxy for average bank size) and the number of banks per square mile. Finally, the timing of legislation could be explained by banking crises. We capture this by using an indicator for large contractions in loans (above the $75^{\text {th }}$ percentile) in the year prior to the enactment of banking laws.

\subsection{Alternative Theories of the Demand for Regulation}

We now turn to other explanations for the passage of the laws. These alternative theories identify groups that might benefit (or lose) from particular laws.

One possibility that the previous historical account does not refer to, but which is alluded to by Kroszner and Strahan (1999), is that state banking legislation would be supported or opposed by the rival institutions which are not affected directly by regulations but are in competition for the same markets. Applied to the period we examine, this theory suggests that national banks would oppose branching (since branching would allow state banks to expand and compete for market share) and deposit insurance (since it would lower the cost of loans of their competitors). To test this theory, we control for the importance of state banks, relative to national banks, using the share of state banks in a state. We also look at the capital-to-asset ratio of state banks (relative to national banks), since the relative profitability of these banks also could make them more influential in policy formation.

Another theory suggests that the main winners and losers were agents in the private sector, both in manufacturing and agriculture. Branching would allow banks to access a larger deposit base and therefore to provide credit to manufacturing firms. Thus, in states where manufacturing was expanding, manufacturing firms pushed for branching laws. To assess the impact of expected growth in manufacturing, we use the lagged growth rate of value added per firm in manufacturing. Given that growth rates are highly correlated over time, it is reasonable to assume that manufacturing firms are forecasting their future growth using past growth. It also has been argued that firm size might predict the passage of branching, although there are two alternative views. Calomiris and Ramirez (2002) argue that large manufacturing firms stood to gain from branching, since it is easier for large firms to maintain credit relationships with a few larger banks rather than with many small banks. However, it has also been argued that small firms benefit from an increased availability of credit through banks, since larger firms have access to alternative sources of capital (for example Jayaratne and Strahan [1998]), and would thus favor branching. Thus, we also include the average size of manufacturing establishments to account for either theory. 
The agricultural sector is another area with potential winners and losers. Calomiris and Ramirez (2002) argue that certain classes of consumers, in particular large landowners, benefited from dealing with a local unit bank rather than the branch of a larger bank (whereas small farmers would benefit from branches through increased credit). Using a cross-section of 48 states, they provide support for this hypothesis. We use the average size of farms to capture this effect.

Finally, the regulatory process might have been affected by the political composition of the state legislature, since ideological and financial divisions between parties would lead them to support different banking legislation. For example, Republicans could have been more likely to support branching deregulation. Following Kroszner and Strahan (1999), we use two measures of the political alignment of a state: one measures the fraction of the state bodies (assembly, senate, and governor's office) under the control of the Democratic Party $(1 / 3,2 / 3,3 / 3)$; the other is a dummy equal to one if the same party controls all three bodies.

\subsection{Empirical Evidence on Factors Affecting Banking Regulation}

In Table 3, we present evidence on the political economy process described in Sections 4.1 and 4.2. We estimate linear probability models of the likelihood that in any given year a state allowed branching or deposit insurance, for the entire period 1900-1940, controlling for year and state fixed effects. State fixed effects control for time-invariant characteristics that determine selection into regulation. For example, the historical view suggests that agricultural rural states were more likely to adopt deposit insurance; to the extent that this is a fixed characteristic of a state, we can control for it with state fixed effects. We also add the covariates suggested by the theories outlined in Sections 4.1 and 4.2. Therefore, we identify how changes within states over time affected the likelihood of passing (or repealing) a banking law.

We start by looking at the "historic" explanation of the passage of the laws. In columns 1 and 2 we examine percent urban and population. Population is not significant. Percent urban enters with the anticipated sign (but this is reversed in subsequent columns). In columns 3 and 4, we add lagged average bank size, the lagged number banks per square mile, and an indicator for banking crises in previous periods. As predicted by the theory outlined in Section 4.1, we find that states with larger banks were more likely to allow branching and less likely to adopt insurance, but these coefficients are not robust in subsequent specifications (and in fact reverse sign when all controls are included). Neither 
population, the number of banks, nor our indicator for financial crises are significant predictors of the laws. Percent urban enters with the opposite of the expected sign (urban states are less likely to adopt branching).

Next (in columns 5 and 6) we look at whether the importance of state banks relative to national banks may have affected legislation, by including the share of banks that are state banks and the relative profitability of state banks compared to national banks (as measured by the capital-to-asset ratio of state banks divided by the capital-to-asset ratio of national banks). We do find support for the theory that both branching and deposit insurance were more likely to be implemented in states with a relatively larger share of state banks, although the measure of relative profitability is not significant. Also note that once we control for the share of state banks, we find that average bank size is positively associated with deposit insurance and not significantly associated with branching.

In the next two columns, we look at whether manufacturing and agricultural conditions mattered. We do not find that average farm size affected legislation, but we do find that states with larger manufacturing firms were more likely to allow branching and to adopt deposit insurance. This finding is statistically significant. We also find that states where value added in manufacturing was growing were significantly less likely to adopt branching, contradicting the theory that anticipated growth (as measured by past growth) generates demand for branching. ${ }^{14}$ This result suggests instead that economic contractions resulted in legislation.

In columns 9 and 10, we include variables for the political alignment of the state. These variables are not significant in either regression. Finally, when we include all the variables and test the theories against each other (last two columns), we find that there are five significant predictors of banking legislation: states with larger banks were more likely to adopt deposit insurance; states where manufacturing was growing were less likely to allow branching; financial crises increased the likelihood of adopting deposit insurance and decreased the likelihood of adopting branching; and large manufacturing firms and a large share of state banks increased the likelihood of either law. Political variables, population, urban population, and farm size are not statistically significant.

\footnotetext{
${ }^{14}$ Appendix B presents additional evidence on this point. It examines whether manufacturing growth anticipated the adoption of branching, by regressing manufacturing outcomes in period $t$ as a function of legislation in period $t+1$. We look at three periods in which many states adopted branching (1910-1911, 19211924, and 1931-1935). The table shows that there is no significant relationship between growth in manufacturing employment, wages, and value added in the preceding period and the subsequent adoption of branching.
} 
Overall, these results provide only partial support for the historical account of the passage of these laws. To the extent that bank size enters as a significant predictor, it enters with the opposite sign to what the theory predicts (states with larger banks are more likely to adopt deposit insurance). Bank crises (as measured through credit contractions) are however very significant predictors of deposit insurance: it increased the likelihood of adopting insurance by 2.6 percentage points (relative to a mean of 6 percent) and decreased the likelihood of adopting branching by about 10 percentage points.

Instead, we find consistent support for a political-economy story in which the manufacturing and state banking sectors influenced banking reform. The state banking sector as a whole was a direct potential beneficiary of either law, and we do find that a relatively large state banking sector is significantly associated with branching and deposit insurance: a one percent increase in the share of state banks increased the probability of adopting insurance by 20 percent, and it also increased the probability of adopting branching by 2.4 percent. The manufacturing sector also stood to gain from branching, and we find that states with large manufacturing establishments were more likely to adopt branching. A 10-person increase in the number of employees per manufacturing firm raised the probability of adopting branching by 16 percent, but had no effect on adopting insurance. On the other hand we find that states where manufacturing was growing were less likely to adopt branching: a one point increase in the growth rate of value added in manufacturing lowered the probability of adopting branching by about 20 percent. This suggests that manufacturing states adopted branching in response to economic downturns rather than in anticipation of future growth.

\section{Main Results}

We begin by examining the effect of the laws on banking outcomes and then examine their effect on farming, manufacturing, and human capital outcomes. In this section we include state fixed effects and time fixed effects in the specification. In Section 6, we add timevarying controls for economic conditions and for those variables that were found to be significant predictors of banking regulation in the previous section.

We start by looking at the effect on the banking sector (Table 4a). First, we examine whether allowing banks to branch did in fact increase the number of branches in a state and the number of banks with branches, and also examine whether repealing branching laws led to a reduction in branching. We split the data into two sub-samples. In columns 1 and 2 , for states that adopted branching during our period, we see that the number of branches and the 
number of banks with branches were higher (about twice the sample mean) immediately after branching was adopted and also in subsequent years, relative to years when branching was not allowed. In columns 3 and 4, in states that repealed branching, we find that repealing branching (and not allowing branching) results in fewer banks with branches and fewer branches relative to years in which branching was permitted. This evidence suggests that branching laws were implemented and effective in both directions.

Next we look at the effect of the laws on banking activity as measured by bank loans, using our main specification which uses the entire data set and includes state and year fixed effects. For the growth of state bank loans, the insurance and branching effects are significant and have the expected signs: loans in states with deposit insurance grew more rapidly prior to 1920 and less rapidly in the 1920s, and credit expanded more rapidly in states with branching. Because there appear to be some outliers in the summary statistics, we re-estimate the results by dropping the observations corresponding to the top and bottom 1 percent of growth rates. The results remain statistically significant and mostly unaffected in magnitude, in spite of the reduction in sample size. The magnitude of the effects is large. Relative to an average growth rate of 3 percent and a standard deviation of 17 percent, the effect of branching is about 2 percentage points. The main effect of insurance is somewhat larger in magnitude ( 3 percentage points), and the insurance-in-the1920s effect is even bigger at about 14 percentage points. ${ }^{15}$

An important question is whether these laws permanently increased the growth rate, as our previous specification might suggest. In order to investigate this, we look at the effect of the number of years that the laws have been in place, and allow the effect of the laws to fade over time by including a quadratic in this variable. For branching, we find that the maximum effect of the laws comes four years after it is adopted, and that the effect on the growth rate fades away after 10 years. We find a similar time-profile for the negative effect of deposit insurance.

In Table $4 \mathrm{~b}$ we examine the effect of regulation on various components of growth, starting with the agricultural sector. For (the log of) the number of farms, the coefficients are not statistically significant. The next row reveals that the amount of land devoted to agriculture was affected: branching and deposit insurance appear to decrease farm land (by about 14 and 6 percent respectively), whereas deposit insurance in the 1920s has the opposite effect. All of the coefficients are statistically significant. In the next row, we see 
that the value of machines and implements used per acre increased significantly, by about 40 percent in states with deposit insurance (the effect of branching is positive, but not significant). In this sense it would appear that, although there was less land devoted to agriculture, land was farmed more intensively in states with greater access to credit. Finally, on the output side of the farming sector, we see that increased access to credit through deposit insurance led to a decline in the value of crops produced per farm: the effect of deposit insurance is negative (with a magnitude of 8 percent relative to the mean). In contrast, the effect of branching is positive, although not significant. But when we look at the effect of branching on cash receipts per farm (a measure of profitability, only available after 1930), we find that branching led to more profitable farms. To the extent that the expansion of credit associated with deposit insurance was indiscriminate and banks did not necessarily finance the best projects, this illustrates that access to credit does not always have a positive effect. On the other hand, branching appeared to have been beneficial to growth. However these results must be interpreted with caution, because of the small sample sizes.

In the subsequent rows, we examine the effect of the laws on the manufacturing sector. For branching, we find a uniformly positive and significant effect on employment per establishment, log wages, and per capita value added. The magnitude of these effects is large, about 7 percent for employment, 3 percent for wages, and 17 percent for value added. Given that both employment and wages increase, this result is consistent with an increase in labor demand by manufacturing firms. For deposit insurance, again we find a more equivocal set of results. Deposit insurance significantly increased employment and value added, and it had a positive but insignificant effect on wages. However, the effect of deposit insurance in the 1920s is always negative, statistically significant, and more than offsets the positive effect prior to 1920 for wages and value added. These results suggest that manufacturing benefited from increased credit through branching, but was hurt overall by deposit insurance.

Finally, we consider whether there is an effect of these laws on child labor. To the extent that children were mostly employed by the agricultural sector (in 1910, 72 percent of children 10-15 years of age engaged in gainful occupations were employed in agriculture; Bureau of the Census [1924]), changes in the availability of credit that resulted in a transition away from agriculture should result in a permanently reduced demand for child

${ }^{15}$ These findings suggest that the results of Calomiris (1992) and White (1983) regarding the impact of these 
labor. ${ }^{16}$ Because we only have data every ten years, we use the number of years that the state had deposit insurance or branching as the explanatory variables. The results suggest that branching lowered child labor, but only for boys. On the other hand, deposit insurance increased child labor before 1920 and decreased it in the 1920s. This may be explained by the fact that boys were more likely to work in agriculture (see summary statistics) and deposit insurance was adopted mainly in agricultural states, thus increasing credit to agriculture.

\section{Further Sensitivity Checks}

\subsection{Controlling for Economic Conditions}

One possible concern with these results is that we do not include any measures of economic conditions, which could affect our outcomes and also be correlated with the passage of legislation. In order to control for the effect of time-varying macroeconomic conditions within a state, we use a comparison group: national banks within the same state. As Figure 2 suggests, the time-series trends in state bank loans and national bank loans are very similar, lending credence to the argument that the growth rate of loans of national banks can provide a good control for macroeconomic trends and temporary shocks at the state level.

In controlling for the performance of national banks, the main issue is that these banks could have been affected by state-level regulations. To the extent that these laws applied only to state banks, there is no direct effect on national banks. But there could be indirect effects because of competition and the interdependence of banks (as discussed in Section 4.2).

We assess the empirical relevance of this effect in the first row of Table 5 by looking at the effect of the laws on the growth rate of national bank loans prior to 1930 . The coefficients are not only insignificant but also relatively small in magnitude. They range from 0.1 to 0.8 percentage points, relative to a mean of 4.5 . So although in theory one may expect to find significant effects, we find no empirical support to suggest that national banks were affected by the laws. We opt to control for national banks in order to test whether the results are sensitive to this proxy of state-level economic conditions, although we note that we might be over-controlling if national banks are indeed affected by

laws are robust to the extended sample period and to the inclusion of state and year fixed effects. 
the legislation. In order to minimize this problem we restrict our sample to the pre-1930 period (prior to the Glass-Steagall Act of 1933, which allowed national banks to branch within states that allowed branching; see Bradford [1940, p. 20]). The measured effects in this specification capture the partial effect of legislation, net of its effect through national banks.

The results controlling for national banks are in the subsequent rows of Table 5. The coefficients on the growth rate of state bank loans and manufacturing outcomes are very similar to those presented in Tables $4 \mathrm{a}$ and $4 \mathrm{~b}$. Our results for agriculture are also similar, with a few exceptions. The effect of deposit insurance before 1920 drops to roughly half for farm land and machinery per acre, making the overall effect of deposit insurance on agriculture (the sum of the effect before and after 1920) negative. As before, branching increases cash receipts per farm. But now branching is associated with a larger decrease in the number of farms and farm land. Lastly note that the inclusion of national banks as a control affects the coefficients on child labor: branching still only significantly affects male child labor but the coefficient falls, and deposit insurance is only significant for males after 1920 .

Overall, we find the results (except for child labor) to be robust to the inclusion of national banks as a control. This suggests that economic conditions at the state level are not driving our results for the effect of banking legislation.

\subsection{Endogeneity and Additional Time-Varying Controls}

Since we do not have access to a valid instrumental variable to cleanse our estimates of all possible endogeneity bias, our strategy consists of controlling for time-varying factors that might confound a causal interpretation of our findings. Our previous analysis on the determinants of the legislation found five significant predictors (state bank size, banking crises in previous periods, the share of state banks, the lagged growth rate of manufacturing, and the average size of manufacturing firms in the previous period). To the extent that our results remain robust when we include these additional controls, we will have added confidence in a causal interpretation of our results.

These results are shown in Table 6. The coefficients for branching on the growth rate of loans and on all agricultural outcomes remain unchanged: that is, branching significantly increases the growth rate of loans, reduces farm size, and increases cash

\footnotetext{
${ }^{16}$ Furthermore, access to credit at the household level should lead to a reduction in child labor, because it allows households to insure against income shocks, and possibly to borrow (either directly or indirectly) to
} 
receipts per farm. Its effect is still positive and significant for all manufacturing outcomes, although the coefficients are smaller; ${ }^{17}$ and negative and significant for (male and female) child labor (but the effects are also smaller than in Table 4b, about 1.6 percent for males and 3 percent for females).

Deposit insurance still significantly decreases the growth rate of loans in the 1920s, but its positive effect prior to the 1920s is smaller and no longer significant. The effect of deposit insurance on the number of farms and on acres of farm land also disappears. However, we still find that deposit insurance led to more machines per acre and to lower value of crops. For manufacturing, the effects on employment are unchanged. But again the positive pre-1920 effect on value-added disappears, whereas the post-1920 effect remains. Finally, there are no longer any effects of deposit insurance on child labor.

Overall, these results suggest that deposit insurance negatively affected outcomes, and that its apparent benefits are not robust to the inclusion of controls. On the other hand branching appears to be very robust to the inclusion of controls. Again it is worth noting that our sample size for some of these outcomes is small.

\subsection{The Effects of Banking Laws on State Personal Income}

Table 7 presents our results using estimates of per capita personal income at the state level. Recall that these estimates are available only for some years (1900, 1919-1921, 1929-1940) and therefore we cannot effectively capture the effect of the changes in legislation that took place in the 1900s and 1910s.

We use these data to look at the overall effect of the laws on economic performance. In particular, we look at the effect of the laws on the annual growth rate of state per capita income. We can compute annual growth rates for the years 1920, 1921, and 1930 through 1940. As in our main specifications, in this regression we control for state and year fixed effects and use population weights. We find that growth in per capita income was significantly lower in those states and years in which deposit insurance was in

place. This is consistent with Tables $4 \mathrm{~b}, 5$, and 6 , in which we find a negative effect of post-1920 deposit insurance. For branching we find that its overall effect was positive and significant: state per capita income grew 6 percentage points faster in those states and years that allowed branching.

facilitate children's education. See Baland and Robinson (2000). 


\section{Discussion}

Overall, our results seem to suggest that the impact of branching and deposit insurance on real economic activity differ. For farm outcomes, deposit insurance drove down the value of crops produced per farm, even in the pre-1920 period. For manufacturing, deposit insurance seems to have had a negative effect on employment and value added and perhaps on wages as well. Moreover, even though deposit insurance appeared to have an initial positive impact, the effect is explained away entirely once we control for economic conditions and the potential endogeneity of the laws. Most of our results suggest that the overall impact of deposit insurance was negative. And these negative effects, when significant, are sizable. The reduction in the growth rate of state bank loans is about one standard deviation. The decrease in value-added in manufacturing associated with deposit insurance was about 20 percent in the 1920s.

In contrast, the effect of branching is much more uniform. For farms, in the post1930 period there was a robustly positive effect on farm cash receipts and for all manufacturing outcomes the effect of branching was uniformly and significantly positive. The effect on cash receipts per farm is large (about 25 percent) and it presumably results from inducing farm consolidation (fewer and more intensely cultivated farms).

We do find large effects of branching on the manufacturing sector: states with branching had seven percent higher employment in manufacturing, manufacturing wages that were two percent higher, and value-added in manufacturing that was more than ten percent higher. This makes sense in the context of banking in the first half of the century. In this period, banking was widely influenced by the real-bills doctrine, which held that loans by banks should primarily facilitate the production (storage, shipment, etc.) of goods and should be short term in nature. See James (1978) and White (1997). In 1909, such time loans constituted 47 percent of national banks' portfolios and 42 percent of state banks' portfolios. Thus, it is not surprising that the financial development induced by branching and deposit insurance laws had a substantial impact on the manufacturing sector. Our results are consistent with increases in labor demand in manufacturing.

The effects of branching on child labor are also large: branching lowers child labor by about 0.1 percent for each year it is in place. So, for example, male child labor was

\footnotetext{
${ }^{17}$ Note that we do not include lagged firm size as a control in the regression of firm size because in our panel setting using a lagged dependent variable as a control generates bias. The results for firm size are very robust to inclusion of covariates but they change dramatically when lagged firm size is included.
} 
between 5 and 14 percent lower in states that had allowed branching for 3 years. (It should be noted that the effect is not significant for girls when we include national banks loans as a control.) Presumably, there are both direct and indirect effects: financial development can directly increase household access to credit, but it also indirectly shifts the economy away from agriculture (where child labor was used more readily) to manufacturing (where it was more difficult to employ children) and increases mechanization. However these results are sensitive to the inclusion of controls, so they must be interpreted with caution.

\section{Conclusion}

This paper has examined the link between financial development and components of economic growth. Our results demonstrate a strong link between state bank branching and deposit insurance regulation and activity in the banking, farming, and manufacturing sectors. Our results remain robust to an array of specification checks.

Although we find that financial development has an important impact on growth, this effect is not always positive. We show that indiscriminate expansions of credit, such as the one that resulted from deposit insurance laws, can have a negative impact on growth. In contrast, the effect of branching on manufacturing activity is uniformly positive. Thus, our results suggest an important qualification to the literature that has documented a positive relationship between financial development and growth: whereas financial development can contribute to growth, the choice of institutional mechanism to induce financial development matters.

Our results also shed light on the political economy process that brought about the adoption of these laws. Our empirical results support the view that it was mainly the agents directly affected by regulation, namely state banks, that affected the passage of legislation, although we also find that manufacturing interests contributed to the adoption of branching. However, when we examine the impact of the adoption of these laws on their respective constituencies, we find that manufacturing interests uniformly benefited from branching throughout the period we examine. In contrast, state banks and all other agents overall were hurt by adoption of deposit insurance, with the combination of moral hazard and the agricultural price collapse of 1919-20. 


\section{References}

Acemoglu, Daron, and Joshua Angrist (1999). "How Large are the Social Returns to Education? Evidence from Compulsory Schooling Laws," National Bureau of Economic Research Working Paper No. 7444.

------, Simon Johnson, and James Robinson (2000). "The Colonial Origins of Development: An Empirical Investigation," National Bureau of Economic Research Working Paper No. 7771 .

------, ------, and ------ (2001). "Reversal of Fortune: Geography and Institutions in the Making of the Modern World Income Distribution," National Bureau of Economic Research Working Paper No. 8460.

------, ------, and ------ (2001). “Institutional Causes, Macroeconomic Symptoms: Volatility, Crises and Growth,” National Bureau of Economic Research Working Paper No. 9124.

Akerlof, George, Paul Romer, Robert Hall, and Gregory Mankiw (1993), "Looting: The Economic Underworld of Bankruptcy for Profit," Brookings Papers on Economic Activity, $1993,1-73$.

Angrist, Joshua, Guido Imbens, and Donald Rubin (1996), "Identification of Causal Effects Using Instrumental Variables" (with discussion), Journal of the American Statistical Association, 91, 444-72.

Angrist, Joshua, and Alan B. Krueger (1991), "Does Compulsory School Attendance Affect Schooling and Earnings?," Quarterly Journal of Economics, 106, 979-1014.

Baland, Jean-Marie, and James Robinson (2000). "Is Child Labor Inefficient," Journal of Political Economy, 108, 663-679.

Beck, Thorsten, Ross Levine, and Norman Loyza (2000). "Finance and the Source of Growth," manuscript.

Bentson, George and George Kaufman (1997). "FDICIA After Five Years," The Journal of Economics Perspectives, 11, 139-158.

Bertrand, Marianne, Esther Duflo, and Sendhil Mullainathan (2002), "How Much Should We Trust Differences-in-Differences Estimates?" National Bureau of Economic Research Working Paper No. 8841.

Bradford, Frederick A. (1940). The Legal Status of Branch Banking in the United States. New York, NY: American Economists Council for the Study of Branch Banking.

Brewer, Elijah and Thomas Mondschean (1994). "An Empirical Test of the Incentive Effects of Deposit Insurance: The Case of Junk Bonds at Savings and Loans," Journal of Money Credit and Banking, 26, 146-164. 
Botero, Juan, Djankov, Simeon, Rafael La Porta, Florencio Lopez-de-Silanes, and Andei Schleifer (2003). "The Regulation of Labor," National Bureau of Economic Research Working Paper No. 9756.

Calomiris, Charles (1992). "Do 'Vulnerable' Economies Need Deposit Insurance? Lessons from U.S. Agriculture in the 1920s," in Philip L. Brock (ed.), If Texas Were Chile: A Primer on Banking Reform. San Francisco, CA: Institute for Contemporary Studies, pp. 237-349.

----- (2000). U.S. Banking Deregulation in Historical Perspective. New York, NY: Cambridge University Press.

------ and Carlos Ramirez (2002). "The Political Economy of Bank Entry Restrictions: Theory and Evidence from the U.S. in the 1920s," unpublished.

Cameron, Rondo (1967). Banking in Early Stages of Industrialization. New York: Oxford University Press.

Carter, J.M. (1992). Commercial Bank Liquidity Management, Discretionary Reserve Behavior, and the Allocation of Credit, 1873-1913. New York, NY: Garland Publishing.

Cartinhour, Gaines Thomson (1931). Branch, Group, and Chain Banking. New York, NY: MacMillan.

Chapman, John M., and Ray B. Westerfield (1942). Branch Banking. New York, NY: Harper \& Brothers.

Dehejia, Rajeev, and Roberta Gatti (2002), "Child Labor: The Role of Access to Credit and Income Variability," National Bureau of Economic Research Working Paper 9018, forthcoming Economic Development and Cultural Change.

Dell'Ariccia, Giovanni, Enrica Detragiache, and Raghuram Rajan (2005), "The Real Effect of Banking Crises," CEPR Discussion Paper 5088.

Djankov, Simeon, Edward Glaeser, Rafael La Porta, Florencio Lopez-de-Silanes, and Andei Schleifer (2003). "The New Comparative Economics," National Bureau of Economic Research Working Paper No. 9608.

Djankov, Simeon, Rafael La Porta, Florencio Lopez-de-Silanes, and Andei Schleifer (2003). “Courts," Quarterly Journal of Economics, 118, 453-517.

Economides, N., R. Glenn Hubbard, and D. Palia (1996). "The Political Economy of Branching Restrictions and Deposit Insurance: A Model of Monopolistic Competition among Small and Large Banks," Journal of Law and Economics, 39, 667-704.

Fisher, Stanley (1999), "On the Need for an International Lender of Last Resort," The Journal of Economic Perspectives, Vol. 13, No. 4, pp. 85-104. 
Goldin, Claudia (1998). "How Americans Graduated from High School," National Bureau of Economic Research Working Paper No. W4762, and Appendix, Working Paper No. $\mathrm{H} 0057$.

Goldsmith, Raymond (1969). Financial Structure and Development. New Haven: Yale University Press.

Guiso, Luigi, Paola Sapienza, and Luigi Zingales (2004), "Does Local Financial Development Matter?" Quarterly Journal of Economics, 119, 929-969.

Gurley, John, and Edward Shaw (1960). Money in a Theory of Finance. Washington: Brookings Institute.

James, John A. (1978). Money and Capital Markets in Postbellum America. Princeton, NJ: Princeton University Press.

Jayaratne, Jith, and Philip Strahan (1996), "The Finance-Growth Nexus: Evidence from Bank Branch Deregulation," Quarterly Journal of Economics, 111, 639-670.

------ and ------ (1998), "Entry Restrictions, Industry Evolution and Dynamic Efficiency," Journal of Law and Economics, 41, 239-273.

King, Robert, and Ross Levine (1993). "Finance and Growth: Schumpeter Might be Right," Quarterly Journal of Economics, 108, 717-737.

Kroszner, Randall S (1998). "Rethinking Bank Regulation: A Review of the Historical Evidence," Journal of Applied Corporate Finance, Summer 1998, 48-58.

------, Luc Laeven, and Daniela Klingebiel (2005), "Banking Crises, Financial Dependence, and Growth," manuscript.

------ and Philip E. Strahan (1999), "What Drives Deregulation" Economics and Politics of the Relaxation of Bank Branching Restrictions," Quarterly Journal of Economics, 114, 1437-1467.

Levine, Ross, and Sara Zervos (1998). "Stock Markets, Banks, and Economic Growth," American Economic Review, 88, 537-558.

McKinnon, Robert (1973). Money and Capital in Economic Development. Washington: Brookings Institute.

Mehrling, Perry G. (1997). The Money Interest and the Public Interest. Cambridge, MA: Harvard University Press.

Moehling, Carolyn M. (1999). "State Child Labor Laws and the Decline of Child Labor," Explorations in Economic History, 36, 72-106.

Rajan, Raghuram, and Luigi Zingales (1998). "Financial Dependence and Growth," American Economic Review, 88, 559-586. 
Rousseau, Peter (2002). "Historical Perspectives and Financial Development and Economic Growth," National Bureau of Economic Researching Working Paper No. 9333.

------ and Paul Wachtel (1998). "Financial Intermediation and Economic Performance: Historical Evidence from Five Industrialized Countries," Journal of Money, Credit, and Banking, 30, 657-678.

Shaw, Edward (1973). Financial Deepening in Economic Development. New York: Oxford University Press.

Southworth, Shirley Donald (1928). Branch Banking in the United States. New York, NY: McGraw-Hill.

Sylla, Richard (1969). "Federal Policy, Banking Market Structure, and Capital Mobilization in the United States, 1863-1913," The Journal of Economic History, 29, 657686.

----- (1972). “The United States 1863-1913," in Rondo Cameron (ed.), Banking and Economic Development: Some Lessons of History. New York: Oxford University Press, pp. 232-262.

----- (2002). "Financial Systems and Economic Modernization," The Journal of Economic History, 62, 277-292.

U.S. Bureau of the Census (1960). Historical Statistics of the United States, Colonial Times to 1957. Washington, DC: General Printing Office.

Westerfield, Ray B. (1939). Historical Survey of Branch Banking in the United States. New York, NY: American Economists Council for the Study of Branch Banking.

Wheelock, David C. (1992). "Regulation and Bank Failure: New Evidence from the Agricultural Collapse of the 1920s," Journal of Economic History, 52, 806-825.

------ and Subal C. Kumbhakar (1995). "Which Banks Choose Deposit Insurance? Evidence of Adverse Selection and Moral Hazard in a Voluntary Insurance System," Journal of Money, Credit and Banking, 27, 186-201.

----- and Paul W. Wilson (1995). "Explaining Bank Failures: Deposit Insurance. Regulation, and Efficiency," The Review of Economics and Statistics, 77, 689-700.

White, Eugene Nelson (1981), "State-Sponsored Insurance of Bank Deposits in the United States, 1907-1929," Journal of Economic History, 41, 537-557.

------ (1982), “The Political Economy of Banking Regulation, 1864-1933,” Journal of Economic History, 42, 33-40.

----- (1983). The Regulation and Reform of the American Banking System, 1900-1929. Princeton, NJ: Princeton University Press. 
----- (1997). "Deposit Insurance," in Gerard Caprio, Jr., and Dimitri Vittas (eds.), Reforming Financial Systems: Historical Implications for Policy, Chapter 5. Cambridge: Cambridge University Press, 1997.

White, Lawrence (1993). "A Cautionary Tale of Deregulation Gone Awry: The S\&L Debacle," Southern Economic Journal, 59, 496-514. 


\section{Appendix A: Data Sources}

Banking Data

Data on banking regulations were collected from the following publications: Chapman and Westerfield, "Branch Banking: Its Historical and Theoretical Position in American and Abroad" contains information on branching regulations in 1896. Frederick Bradford, "The Legal Status of Branching in the United States" contains information for the years 1910, 1924, 1929, 1932, 1936, and 1939. We use "State Laws Relating to Branch Banking" (Federal Reserve Bulletin, March 1925) and "Compilation of Federal and State Laws Relating to Branch Banking within the United States" (Federal Reserve Bulletin, November 1936) to time changes in the laws.

State deposit insurance laws are gleaned from secondary sources such as Calomiris or White.

Banking outcomes aggregated at the state level come from the "United States Historical Data on Bank Market Structure, 1896-1955" collected by Flood from several sources. Importantly, these data contain aggregate information for all banks in the state and for national banks. We construct the state bank information as the difference between the two. This means that our measure of state banks also includes some private banks, but we can confirm from All-Bank Statistics that these are small both in number and in size of total deposits.

Data on number of branches and number of banks with branches come from Banking Monetary Statistics and are available for 1900, 1910, 1920, 1925, 1930, 1933 and 1937.

Agricultural Data

Average value of farm property per farm and per acre of farm land was reported in the Statistical Abstract of the United States for 1910, 1920, 1925, 1930 and 1940. The value of farm property is reported in thousands.

The value of farm implements and machinery: nominal value of farm implements and machinery come from The Statistical Abstract of the United States, various numbers.

Farm cash receipts come from the Economic Research Service of the Department of Agriculture, includes total cash receipts by farm and total cash receipts from crops. The difference between the two is essentially livestock (dairy, cattle, poultry, etc.).

Value of crops and value of implements and machinery comes from the "Historical, Demographic, Economic, and Social Data: The United States, 1790-1970”, ICPSR study number 0003, 0007, 0008, 0014, 0017.

Manufacturing Data

Employment in manufacturing, wages in the manufacturing sector and value added in manufacturing comes from the Census of Manufactures, and was reported in various editions of the Statistical Abstract of the United States.

Political Data

The party of the governor and of the state senate and house come from ICPSR, Study number 16, "Partisan Division of American State Governments, 1834-1985, by Burnham, W. Dean.

State-level Personal Income Estimates by Year

Nominal state-level estimates come from three separate sources:

(1) Estimates for 1900 come from Table Y-1 page 753, Population Redistribution and Economic Growth United States, 1970-1950, Volume I, Methodological Considerations and Reference Tables, by Everett S. Lee, Ann Ratner Miller, Carol P. Brainerd and Richard 
Esterlin, prepared under the direction of Simon Kuznets and Dorothy Swaine Thomas. The American Philosophical Society, Independence Square, Philadelphia, 1957.

(2) Estimates for 1919, 1920 and 1921 were reported in Table XLII, page 249, Income in the Various States. Its Sources and Distribution in 1919, 1920 and 1921, by Maurice Leven, National Bureau of Economic Research, 1925.

(3) Estimates for 1929 and beyond were reported in Table 1, page 4, State Personal Income: Estimates for 1929-82 and a Statement of Sources and Methods, U.S. Department of Commerce, Bureau of Economic Analysis, U.S. G.P.O. Washington, DC, 1984.

Other Data

Percentage of children considered child labor, population and percent urban are calculated using the censuses from 1900 to 1940. In all of these censuses, individuals were asked if they were in school anytime in the last year, ${ }^{18}$ and what their occupation was. All children who declared an occupation ${ }^{19}$ were classified as working. ${ }^{20}$ We define child labor as the percentage of children ages 10 to 15 who are not in school and are working. We calculate these state measures by aggregating the individual-level data available from the IPUMS. Although individual-level 1930 census data are not available in electronic format, the relevant state-level information was published by the Census Bureau. See Bibliography below.

All monetary values were converted into real dollars using the Wholesale Price Index series provided by the Bureau of Labor Statistics and available in the Historical Statistics of the United States, Colonial Times to 1957. The base period is 1947-1949.

\footnotetext{
${ }^{18}$ This number overstates the number of children who attended school for several months (see Goldin [1998]).

${ }^{19}$ We used the variable "occ1950". Those with codes less than 980 were considered to be working.

${ }^{20}$ As in Moehling (1999), we use occupation to determine work status. The reason is that labor force status is available in 1910, 1920 and 1940 only for those 16 and above, but occupation was asked of all persons aged 10 and older in of all the relevant censuses.
} 
Appendix B: The Effect of Future Branching on Manufacturing Growth

\begin{tabular}{|c|c|c|c|c|c|c|c|c|c|}
\hline & $\begin{array}{c}\text { (1) } \\
\text { Growth in } \\
\text { employees }\end{array}$ & $\begin{array}{c}(2) \\
\text { Growth } \\
\text { in wages }\end{array}$ & $\begin{array}{c}(3) \\
\text { Growth } \\
\text { in value } \\
\text { added }\end{array}$ & $\begin{array}{c}(4) \\
\text { Growth in } \\
\text { employees }\end{array}$ & $\begin{array}{c}(5) \\
\text { Growth } \\
\text { in wages }\end{array}$ & $\begin{array}{c}(6) \\
\text { Growth } \\
\text { in value } \\
\text { added }\end{array}$ & $\begin{array}{c}(7) \\
\text { Growth in } \\
\text { employees }\end{array}$ & $\begin{array}{c}(8) \\
\text { Growth } \\
\text { in } \\
\text { wages }\end{array}$ & $\begin{array}{c}(9) \\
\text { Growth } \\
\text { in value } \\
\text { added }\end{array}$ \\
\hline $\begin{array}{l}\text { Branching } \\
\text { will be } \\
\text { introduced }\end{array}$ & $\begin{array}{l}-0.013 \\
(0.040)\end{array}$ & $\begin{array}{c}9.95 \mathrm{E}-04 \\
(0.002)\end{array}$ & $\begin{array}{c}-0.013 \\
-0.040)\end{array}$ & $\begin{array}{l}-0.011 \\
(0.13)\end{array}$ & $\begin{array}{l}-0.001 \\
(0.006)\end{array}$ & $\begin{array}{l}-0.011 \\
(-0.13)\end{array}$ & $\begin{array}{l}0.030 \\
(0.19)\end{array}$ & $\begin{array}{c}0.002 \\
(0.008)\end{array}$ & $\begin{array}{l}0.030 \\
(0.19)\end{array}$ \\
\hline $\begin{array}{l}\text { Years for } \\
\text { outcomes }\end{array}$ & $\begin{array}{l}1904, \\
1908\end{array}$ & $\begin{array}{l}1904, \\
1908\end{array}$ & $\begin{array}{l}1904, \\
1908\end{array}$ & $\begin{array}{l}1919, \\
1921\end{array}$ & $\begin{array}{l}1919, \\
1921\end{array}$ & $\begin{array}{l}1919, \\
1921\end{array}$ & $\begin{array}{l}1927, \\
1929\end{array}$ & $\begin{array}{l}1927, \\
1929\end{array}$ & $\begin{array}{l}1927, \\
1929\end{array}$ \\
\hline $\begin{array}{l}\text { Years } \\
\text { branching } \\
\text { introduced }\end{array}$ & $\begin{array}{l}1910- \\
1911\end{array}$ & $\begin{array}{l}1910- \\
1911\end{array}$ & $\begin{array}{c}1910- \\
1911\end{array}$ & $\begin{array}{c}1921- \\
1924\end{array}$ & $\begin{array}{c}1921- \\
1924\end{array}$ & $\begin{array}{c}1921- \\
1924\end{array}$ & $\begin{array}{c}1931- \\
1935\end{array}$ & $\begin{array}{l}1931- \\
1935\end{array}$ & $\begin{array}{l}1931- \\
1935\end{array}$ \\
\hline $\begin{array}{l}\mathrm{N} \\
\mathrm{R} \text {-squared }\end{array}$ & $\begin{array}{l}96 \\
050\end{array}$ & $\begin{array}{c}96 \\
050\end{array}$ & $\begin{array}{l}96 \\
050\end{array}$ & 96 & $\begin{array}{l}96 \\
099\end{array}$ & 96 & 96 & 96 & 96 \\
\hline
\end{tabular}


Figure 1: The Evolution of Branching and State Deposit Insurance Laws

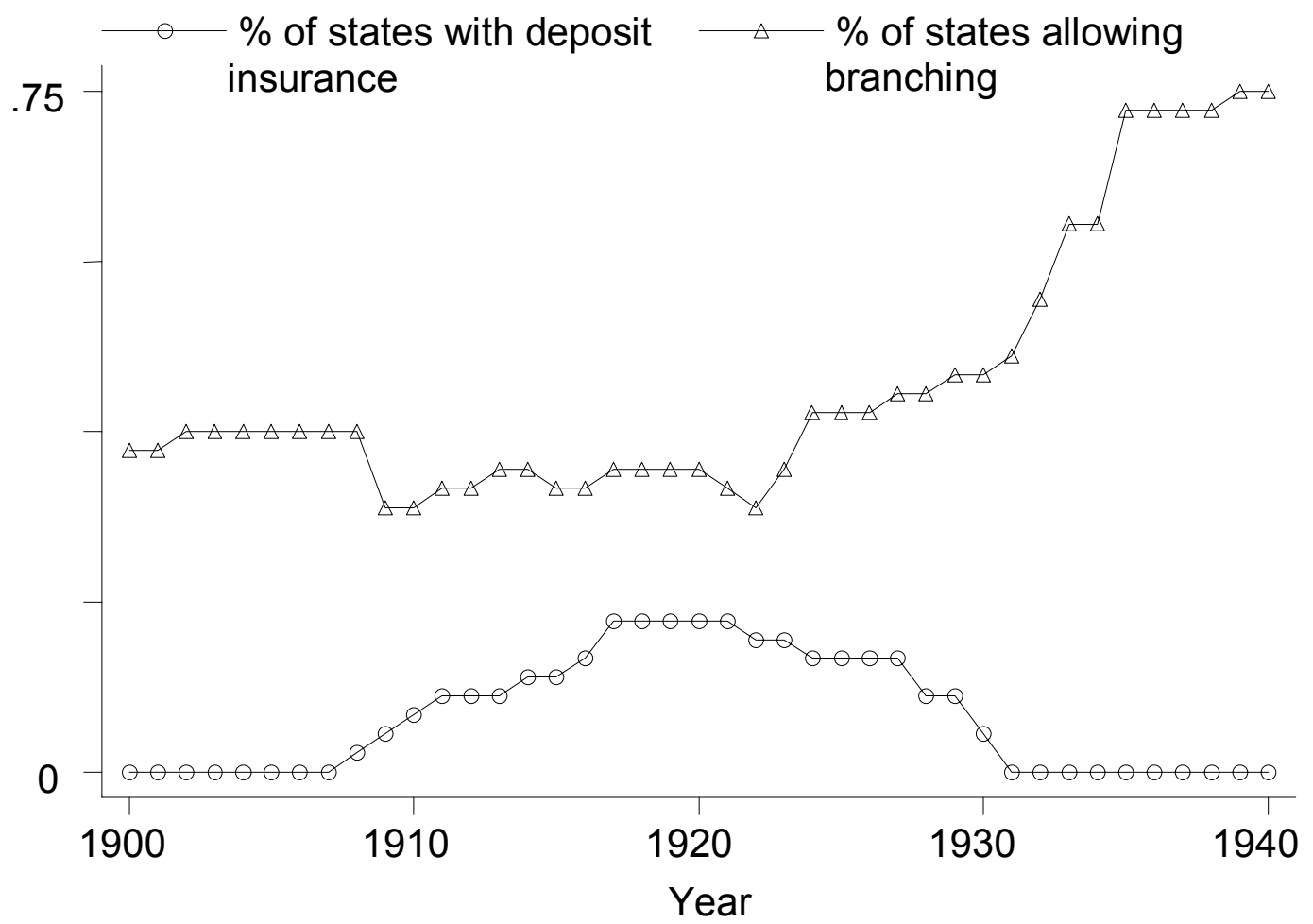

Figure 2: Evolution of Loans, National and State banks.
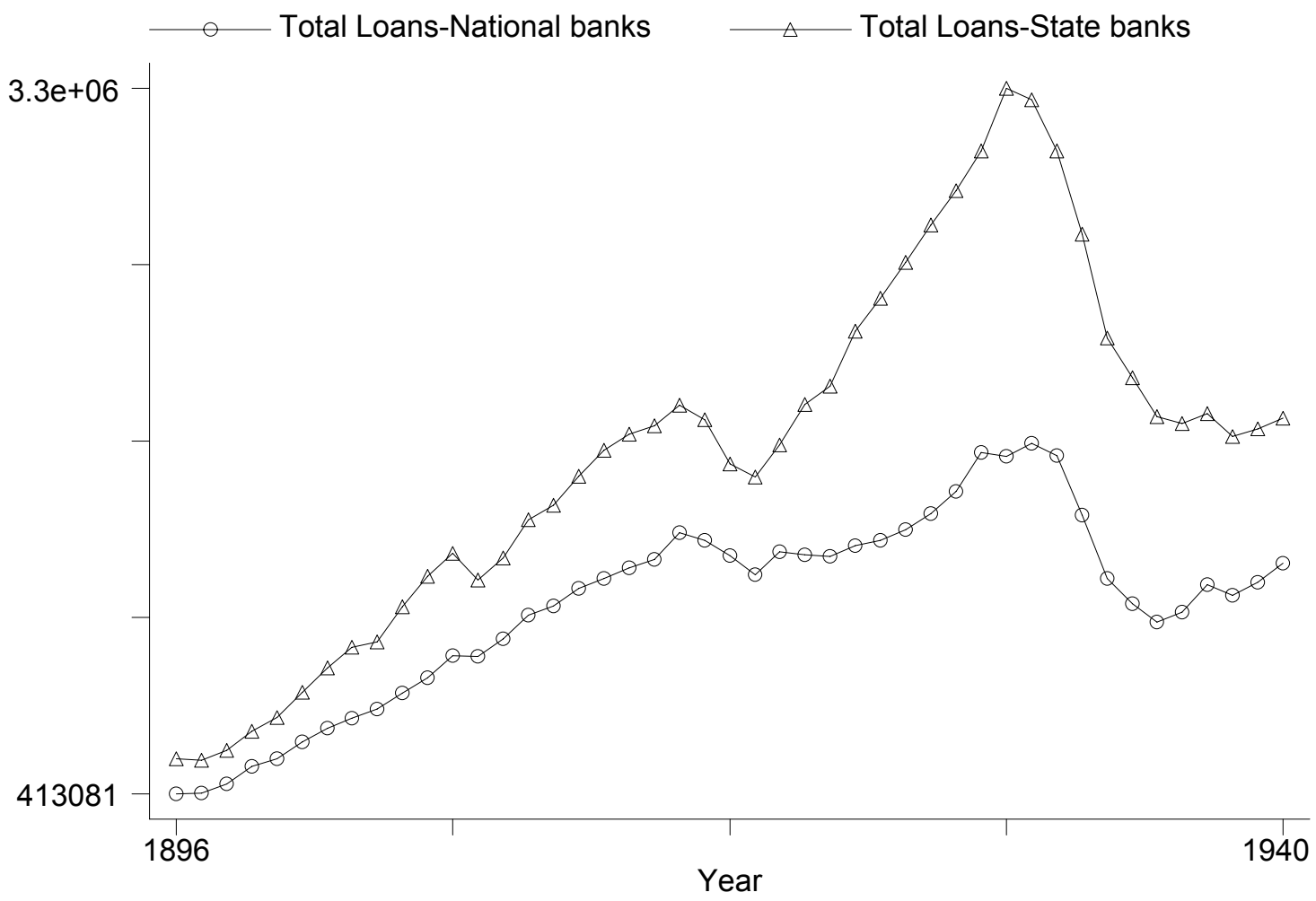

Notes: All monetary values are deflated using the Wholesale Price Index. The base period is $1947-1949$. 
Table 1: State Branching and Deposition Insurance Regulations, Selected Years

State Branching 1900 Branching 1909 Branching 1919 Branching 1929 Branching 1939 Deposit Insurance

\begin{tabular}{|c|c|c|}
\hline Alabama & 0 & 0 \\
\hline Arizona & 1 & 1 \\
\hline Arkansas & 1 & 0 \\
\hline California & 1 & 1 \\
\hline Colorado & 0 & 0 \\
\hline Connecticut & 0 & 0 \\
\hline Delaware & 1 & 1 \\
\hline Florida & 1 & 1 \\
\hline Georgia & 1 & 1 \\
\hline Idaho & 0 & 0 \\
\hline Illinois & 0 & 0 \\
\hline Indiana & 0 & 0 \\
\hline Iowa & 0 & 0 \\
\hline Kansas & 0 & 0 \\
\hline Kentucky & 0 & 1 \\
\hline Louisiana & 1 & 1 \\
\hline Maine & 1 & 1 \\
\hline Maryland & 0 & 0 \\
\hline Massachusetts & 0 & 1 \\
\hline Michigan & 1 & 0 \\
\hline Minnesota & 0 & 0 \\
\hline Mississippi & 0 & 0 \\
\hline Missouri & 0 & 0 \\
\hline Montana & 0 & 0 \\
\hline Nebraska & 0 & 0 \\
\hline Nevada & 1 & 0 \\
\hline New Hampshire & 0 & 0 \\
\hline New Jersey & 0 & 0 \\
\hline New Mexico & 0 & 0 \\
\hline New York & 1 & 1 \\
\hline North Carolina & 1 & 0 \\
\hline North Dakota & 0 & 0 \\
\hline Ohio & 0 & 0 \\
\hline Oklahoma & 0 & 0 \\
\hline Oregon & 1 & 1 \\
\hline Pennsylvania & 0 & 0 \\
\hline Rhode Island & 1 & 1 \\
\hline South Carolina & 0 & 0 \\
\hline South Dakota & 0 & 0 \\
\hline Tennessee & 1 & 1 \\
\hline Texas & 0 & 0 \\
\hline Utah & 0 & 0 \\
\hline Vermont & 0 & 0 \\
\hline Virginia & 0 & 0 \\
\hline Washington & 1 & 1 \\
\hline West Virginia & 0 & 0 \\
\hline Wisconsin & 1 & 0 \\
\hline Wyoming & 0 & 0 \\
\hline
\end{tabular}

\section{0}

\section{1}

1

$$
0
$$$$
0
$$

1

$$
1
$$

0

0

0

1909-1929

$1914-1930$

$1911-1930$

1917-1929

1908-1923

1916-1927

1910-1927

1917-1921

$\begin{array}{lll}0 & 0 & 0\end{array}$

$\begin{array}{lll}0 & 0 & 1\end{array}$

$\begin{array}{lll}0 & 0 & 0\end{array}$ 
Table 2: Descriptive Statistics: State-Level Data

\begin{tabular}{|c|c|c|c|c|c|}
\hline Variable & Obs & Mean & Std. Dev. & Min & Max \\
\hline \multicolumn{6}{|l|}{ Banking Laws (1900-1940) } \\
\hline State has deposit insurance & 1968 & 0.062 & 0.241 & 0.000 & 1.000 \\
\hline State has deposit insurance in 1920s & 1968 & 0.033 & 0.177 & 0.000 & 1.000 \\
\hline State allows branching & 1968 & 0.429 & 0.495 & 0.000 & 1.000 \\
\hline \multicolumn{6}{|l|}{ Bank Outcomes, All Bank Statistics (1900-1940) } \\
\hline Total loans, national banks (in thousands) & 1968 & 207770 & 397107 & 656 & 4362453 \\
\hline Total loans, state banks (in thousands) & 1968 & 322152 & 881035 & 922 & 10800000 \\
\hline Growth rate of assets, national banks & 1968 & 0.045 & 0.123 & -1.138 & 0.948 \\
\hline Growth rate of assets, state banks & 1968 & 0.037 & 0.148 & -1.863 & 0.788 \\
\hline Growth rate of loans, national banks & 1968 & 0.032 & 0.154 & -1.508 & 0.906 \\
\hline Growth rate of loans, state banks & 1968 & 0.026 & 0.177 & -2.290 & 0.798 \\
\hline Deposits per state bank (in thousands) & 1968 & 1938 & 4099 & 51.1 & 50977 \\
\hline Banks per square mile & 1968 & 0.009 & 0.008 & 0.000036 & 0.044 \\
\hline Banks per million residents & 1968 & 192.96 & 164.34 & 16.02 & 1111.85 \\
\hline Indicator for credit contractions $s^{(1)}$ & 1968 & 0.25 & 0.43 & 0 & 1 \\
\hline Proportion of state banks ${ }^{(2)}$ & 1968 & 0.69 & 0.13 & 0.22 & 0.95 \\
\hline Ratio of state to national bank capital-asset ratios & 1968 & 1.07 & 0.44 & 0.026 & 2.74 \\
\hline \multicolumn{6}{|c|}{ Bank Branch Data, Banking and Monetary Statistics $(1900,1910,1920,1925,1930,1933,1937)$} \\
\hline Branches per million residents & 336 & 11.30 & 18.71 & 0 & 132.6 \\
\hline Banks per million residents & 336 & 177.30 & 155.42 & 18.78 & 1109.96 \\
\hline Banks that branch per million residents & 336 & 4.42 & 6.79 & 0 & 43.3 \\
\hline \multicolumn{6}{|c|}{ Census of Agricultural data $(1900,1910,1920,1925,1930,1935,1940)$} \\
\hline Number of Farms & 336 & 131160 & 103215 & 2184 & 501017 \\
\hline Acres agricultural land & 336 & 19918 & 19412 & 222 & 137683 \\
\hline \multicolumn{6}{|c|}{ Value of machinery and implements per acre devoted } \\
\hline to agriculture & 288 & 3423 & 2808 & 259 & 17826 \\
\hline Value of all crops per farm (in millions) & 237 & 0.002 & 0.008 & 0.000 & 0.100 \\
\hline Value of cash receipts per farm (thsds 1935,1940 ) & 192 & 2.066 & 1.184 & 0.459 & 6.245 \\
\hline Lagged farm size ${ }^{(3)}$ & $1920^{*}$ & 0.22 & 0.25 & 0.055 & 1.82 \\
\hline \multirow{2}{*}{\multicolumn{6}{|c|}{ Census of Manufactures data $(1899,1904,1908,1914,1919,1921,1923,1925,1927,1929,1931,1933}}$, \\
\hline & & & & & \\
\hline Employment per establishment & 672 & 34.53 & 20.43 & 1 & 117.68 \\
\hline Annual wage earnings per worker & 672 & 5675 & 2837 & 391 & 11151 \\
\hline Value added per capita & 672 & 0.156 & 0.115 & 0.013 & 0.534 \\
\hline Lagged growth in value added per establishment & $1968^{*}$ & 0.034 & 0.18 & -2.53 & 3.67 \\
\hline Lagged firm size & $1968^{*}$ & 30.0 & 18.8 & 1.00 & 118 \\
\hline \multicolumn{6}{|l|}{ Census Data $(1900,1910,1920,1930,1940)$} \\
\hline Percent males $10-15$ working and not in school & 240 & 0.062 & 0.075 & 0.000 & 0.368 \\
\hline Percent females $10-15$ working and not in school & 240 & 0.029 & 0.044 & 0.000 & 0.350 \\
\hline Percent urban & $1968^{*}$ & 0.420 & 0.212 & 0.062 & 0.975 \\
\hline Population in millions & $1968^{*}$ & 2.19 & 2.18 & 0.042335 & 13.5 \\
\hline \multicolumn{6}{|l|}{ Political Data (1900-1940) } \\
\hline Indicator of Democratic control $^{(4)}$ & 1968 & 0.48 & 0.44 & 0 & 1 \\
\hline Governor and legislature are the same party & 1968 & 0.75 & 0.43 & 0 & 1 \\
\hline \multicolumn{6}{|l|}{ Estimates of Per Capita Personal Income } \\
\hline$(1900,1919-1921,1929-1940)$ & 768 & 577.13 & 423.93 & 127.32 & 10430.98 \\
\hline \multicolumn{6}{|c|}{ Other Data (Statistical Abstract of the United States) } \\
\hline State land area (square miles) & 1968 & 62944 & 46872 & 1212 & 266807 \\
\hline
\end{tabular}

Notes: * Denotes series that interpolated. (1) Indicator for credit contractions denotes states and years in which state bank loans contracted by more than 4 percent (the $25^{\text {th }}$ percentile of the distribution of change in state bank credit). (2) Proportion of state banks is the proportion of state banks relative to state and national banks. (3) Farm size is computed as number of acres devoted to agriculture divided by number of farms in a state. (4) Indicator of democratic control adds $1 / 3$ for each of the lower house, upper house, and governorship Democrats control in each state. 

Table 3: Predicting Passage of Branching and Insurance Laws, Linear Probability Models

\begin{tabular}{|c|c|c|c|c|c|c|c|c|c|c|c|c|}
\hline Dependent Variable: & Branching & Insurance & Branching & Insurance & Branching & Insurance & Branching & Insurance & Branching & Insurance & Branching & Insurance \\
\hline percent urban population & $\begin{array}{c}0.46 \\
(0.31)\end{array}$ & $\begin{array}{c}-0.31 * * \\
(0.14)\end{array}$ & $\begin{array}{l}-0.99 * * \\
(0.46)\end{array}$ & $\begin{array}{l}0.064 \\
(0.21)\end{array}$ & $\begin{array}{l}0.050 \\
(0.98)\end{array}$ & $\begin{array}{l}-0.63 \\
(0.43)\end{array}$ & $\begin{array}{l}-0.59 \\
(0.85)\end{array}$ & $\begin{array}{l}-0.88^{*} \\
(0.47)\end{array}$ & $\begin{array}{l}-0.43 \\
(0.86)\end{array}$ & $\begin{array}{l}-0.72^{*} \\
(0.40)\end{array}$ & $\begin{array}{l}-0.18 \\
(0.97)\end{array}$ & $\begin{array}{l}-0.65 \\
(0.44)\end{array}$ \\
\hline Population in millions & $\begin{array}{c}0.0256 \\
(0.0188)\end{array}$ & $\begin{array}{c}0.00438 \\
(0.00737)\end{array}$ & $\begin{array}{l}-0.0183 \\
(0.0160)\end{array}$ & $\begin{array}{c}0.0114 \\
(0.008 .32)\end{array}$ & $\begin{array}{c}-0.004 .05 \\
(0.0767)\end{array}$ & $\begin{array}{l}0.00534 \\
(0.0123)\end{array}$ & $\begin{array}{l}-0.00541 \\
(0.0597)\end{array}$ & $\begin{array}{l}0.00805 \\
(0.0117)\end{array}$ & $\begin{array}{l}-0.0275 \\
(0.0672)\end{array}$ & $\begin{array}{l}-0.0004 .6 \\
(0.00958)\end{array}$ & $\begin{array}{c}0.0153 \\
(0.0734)\end{array}$ & $\begin{array}{l}0.00449 \\
(0.0130)\end{array}$ \\
\hline $\begin{array}{l}\text { log lagged deposits per state } \\
\text { bank }\end{array}$ & & & $\begin{array}{c}0.35^{* * *} \\
(0.059)\end{array}$ & $\begin{array}{l}-0.072 * \\
(0.044)\end{array}$ & $\begin{array}{l}-0.001 \\
(0.16)\end{array}$ & $\begin{array}{l}0.16 * * * \\
(0.064)\end{array}$ & & & & & $\begin{array}{l}-0.054 \\
(0.15)\end{array}$ & $\begin{array}{l}0.15 * * * \\
(0.063)\end{array}$ \\
\hline $\begin{array}{l}\text { Lagged banks per square } \\
\text { mile }\end{array}$ & & & $\begin{array}{l}-4.45 \\
(6.22)\end{array}$ & $\begin{array}{l}-0.88 \\
(2.18)\end{array}$ & $\begin{array}{c}2.96 \\
(12.7)\end{array}$ & $\begin{array}{l}-9.08 \\
(6.92)\end{array}$ & & & & & $\begin{array}{l}5.65 \\
(13.0)\end{array}$ & $\begin{array}{l}-7.80 \\
(6.47)\end{array}$ \\
\hline $\begin{array}{l}\text { Indicator for credit } \\
\text { contractions }\end{array}$ & & & $\begin{array}{c}0.022 \\
(0.025)\end{array}$ & $\begin{array}{c}0.009 \\
(0.009)\end{array}$ & $\begin{array}{l}-0.039 \\
(0.026)\end{array}$ & $\begin{array}{c}0.037 * * * \\
(0.015)\end{array}$ & & & & & $\begin{array}{l}-0.045^{*} \\
(0.026)\end{array}$ & $\begin{array}{c}0.036 * * * \\
(0.015)\end{array}$ \\
\hline Proportion of state banks & & & & & $\begin{array}{l}1.28^{*} \\
(0.66)\end{array}$ & $\begin{array}{l}1.29 * * \\
(0.60)\end{array}$ & & & & & $\begin{array}{l}1.04^{*} \\
(0.61)\end{array}$ & $\begin{array}{l}1.25^{* *} \\
(0.59)\end{array}$ \\
\hline $\begin{array}{l}\text { Ratio of state to national } \\
\text { bank capital-asset ratios }\end{array}$ & & & & & $\begin{array}{l}0.007 \\
(0.13)\end{array}$ & $\begin{array}{c}0.020 \\
(0.048)\end{array}$ & & & & & $\begin{array}{l}0.021 \\
(0.11)\end{array}$ & $\begin{array}{c}0.025 \\
(0.049)\end{array}$ \\
\hline $\begin{array}{l}\text { Lagged growth of } \\
\text { value added per firm }\end{array}$ & & & & & & & $\begin{array}{c}-0.086^{* * * *} \\
(0.034)\end{array}$ & $\begin{array}{l}-0.013 \\
(0.019)\end{array}$ & & & $\begin{array}{c}-0.082 * * \\
(0.037)\end{array}$ & $\begin{array}{l}-0.003 \\
(0.020)\end{array}$ \\
\hline $\begin{array}{l}\text { Lagged employment } \\
\text { per firm }\end{array}$ & & & & & & & $\begin{array}{l}0.008 * * \\
(0.003)\end{array}$ & $\begin{array}{c}0.002 * * * \\
(9.50 \mathrm{E}-04)\end{array}$ & & & $\begin{array}{l}0.007 * * \\
(0.003)\end{array}$ & $\begin{array}{c}0.001 \\
(7.13 \mathrm{E}-04)\end{array}$ \\
\hline Lagged farm size & & & & & & & $\begin{array}{c}0.28 \\
(0.39)\end{array}$ & $\begin{array}{l}-0.084 \\
(0.26)\end{array}$ & & & $\begin{array}{c}0.34 \\
(0.38)\end{array}$ & $\begin{array}{l}-0.037 \\
(0.20)\end{array}$ \\
\hline $\begin{array}{l}\text { Indicator of Democratic } \\
\text { control }\end{array}$ & & & & & & & & & $\begin{array}{c}0.018 \\
(0.064)\end{array}$ & $\begin{array}{c}0.050 \\
(0.031)\end{array}$ & $\begin{array}{c}0.044 \\
(0.057)\end{array}$ & $\begin{array}{c}0.050 \\
(0.030)\end{array}$ \\
\hline $\begin{array}{l}\text { Governor and } \\
\text { legislature controlled }\end{array}$ & & & & & & & & & $\begin{array}{l}-0.012 \\
(0.042)\end{array}$ & $\begin{array}{l}-0.001 \\
(0.013)\end{array}$ & $\begin{array}{c}-0.016 \\
(0.038)\end{array}$ & $\begin{array}{l}-0.005 \\
(0.012)\end{array}$ \\
\hline $\mathrm{N}$ & 1968 & 1968 & 1920 & 1920 & 1920 & 1920 & 1920 & 1920 & 1968 & 1968 & 1920 & 1920 \\
\hline $\mathrm{R}^{2}$ & 0.12 & 0.06 & 0.35 & 0.11 & 0.67 & 0.53 & 0.68 & 0.48 & 0.66 & 0.46 & 0.69 & 0.53 \\
\hline
\end{tabular}


Notes: All specifications include state and year fixed effects. Robust standard errors in parenthesis. ${ }^{*}$ significant at 10 percent; ** significant at 5 percent; *** significant at 1 percent 
Table 4a: Effect on banking laws on Banking outcomes Fixed Effects Results, No Controls

\begin{tabular}{|c|c|c|c|c|c|c|c|}
\hline $\begin{array}{l}\text { Dependent } \\
\text { variable: }\end{array}$ & $\begin{array}{l}\text { Number of } \\
\text { Branches per } \\
\text { million } \\
\text { residents }\end{array}$ & $\begin{array}{l}\text { Number } \\
\text { of Banks } \\
\text { that } \\
\text { branch } \\
\text { per } \\
\text { million } \\
\text { residents }\end{array}$ & $\begin{array}{l}\text { Number of } \\
\text { Branches } \\
\text { per million } \\
\text { residents }\end{array}$ & $\begin{array}{c}\text { Number of } \\
\text { Banks that } \\
\text { branch per } \\
\text { million } \\
\text { residents }\end{array}$ & $\begin{array}{l}\text { Growth rate } \\
\text { of loans }\end{array}$ & $\begin{array}{l}\text { Growth rate } \\
\text { of loans }\end{array}$ & $\begin{array}{c}\text { Quadratic in } \\
\text { number of } \\
\text { years with } \\
\text { branching } \\
\text { and } \\
\text { insurance }\end{array}$ \\
\hline Sample & \multicolumn{2}{|c|}{ States that never repealed } & \multicolumn{2}{|c|}{ States that repealed } & All & Drop outliers & All \\
\hline $\begin{array}{l}\text { Branching } \\
\text { passed }\end{array}$ & $\begin{array}{c}10.1 * * * \\
(3.22)\end{array}$ & $\begin{array}{c}4.27 * * * \\
(1.81)\end{array}$ & & & & & \\
\hline $\begin{array}{l}\text { Branching } \\
\text { allowed }\end{array}$ & $\begin{array}{c}14.6^{* * *} \\
(4.40)\end{array}$ & $\begin{array}{l}6.28^{* *} \\
(2.74)\end{array}$ & & & & & \\
\hline $\begin{array}{l}\text { Branching } \\
\text { repealed }\end{array}$ & & & $\begin{array}{c}-19.5^{* *} \\
(9.85)\end{array}$ & $\begin{array}{c}-4.88^{* * * *} \\
(0.77)\end{array}$ & & & \\
\hline $\begin{array}{l}\text { Branching not } \\
\text { allowed }\end{array}$ & & & $\begin{array}{l}-10.8 \\
(8.31)\end{array}$ & $\begin{array}{l}-2.88 \\
(2.37)\end{array}$ & & & \\
\hline $\begin{array}{l}\text { Deposit } \\
\text { insurance } \\
\text { before } 1920\end{array}$ & & & & & $\begin{array}{c}0.037 * * * \\
(0.015)\end{array}$ & $\begin{array}{c}0.033 * * * \\
(0.010)\end{array}$ & \\
\hline $\begin{array}{l}\text { Deposit } \\
\text { insurance } \\
\text { after } 1920\end{array}$ & & & & & $\begin{array}{c}-0.14 * * * \\
(0.028)\end{array}$ & $\begin{array}{c}-0.12 * * * \\
(0.020)\end{array}$ & \\
\hline Branching & & & & & $\begin{array}{c}0.021^{* *} \\
(0.011)\end{array}$ & $\begin{array}{c}0.022 * * * \\
(0.009)\end{array}$ & \\
\hline $\begin{array}{l}\text { Years with } \\
\text { deposit } \\
\text { insurance }\end{array}$ & & & & & & & $\begin{array}{c}-0.019 * * \\
(0.009)\end{array}$ \\
\hline $\begin{array}{l}\text { (Years with } \\
\text { deposit } \\
\text { insurance) })^{2}\end{array}$ & & & & & & & $\begin{array}{c}0.002 \\
(0.001)\end{array}$ \\
\hline $\begin{array}{l}\text { Years with } \\
\text { branching }\end{array}$ & & & & & & & $\begin{array}{c}0.011^{* * *} \\
(0.005)\end{array}$ \\
\hline $\begin{array}{l}\text { (Years with } \\
\text { branching) }\end{array}$ & & & & & & & $\begin{array}{c}-0.0013^{* * * *} \\
(5.65 \mathrm{E}-04)\end{array}$ \\
\hline Observations & 140 & 140 & 56 & 56 & 1968 & 1932 & 1968 \\
\hline R-squared & 0.70 & 0.49 & 0.67 & 0.54 & 0.62 & 0.63 & 0.62 \\
\hline
\end{tabular}


Table 4b: Effect on banking laws on economic outcomes Fixed Effects Results, No Controls

\begin{tabular}{|c|c|c|c|c|c|}
\hline & $\begin{array}{c}\text { Deposit Insurance } \\
\text { before } 1920\end{array}$ & $\begin{array}{l}\text { Deposit Insurance } \\
\text { after } 1920\end{array}$ & Branching & $\begin{array}{c}\text { Number of } \\
\text { observations }\end{array}$ & $\begin{array}{l}\text { Within- } \\
\text { state } \mathrm{R}^{2}\end{array}$ \\
\hline \multicolumn{6}{|l|}{ Agricultural outcomes } \\
\hline Log number of farms & $\begin{array}{c}-0.046 \\
(0.061)\end{array}$ & $\begin{array}{c}0.044 \\
(0.051)\end{array}$ & $\begin{array}{l}-0.054 \\
(0.040)\end{array}$ & 336 & 0.21 \\
\hline Log acres agricultural land & $\begin{array}{c}-0.14 * * * \\
(0.041)\end{array}$ & $\begin{array}{c}0.082 * * * \\
(0.034)\end{array}$ & $\begin{array}{c}-0.057^{* *} \\
(0.029)\end{array}$ & 336 & 0.09 \\
\hline Value of machines per acre & $\begin{array}{c}1354 * * * \\
(413)\end{array}$ & $\begin{array}{c}-642 * * * \\
(271)\end{array}$ & $\begin{array}{c}462 \\
(552)\end{array}$ & 288 & 0.56 \\
\hline Value of crops per farm & $\begin{array}{l}-2.57 \mathrm{e}-04 * * * \\
(1.05 \mathrm{e}-04)\end{array}$ & $\begin{array}{l}-1.52 \mathrm{e}-04 \\
(2.91 \mathrm{e}-04)\end{array}$ & $\begin{array}{l}6.13 \mathrm{e}-05 \\
(1.01 \mathrm{e}-04)\end{array}$ & 237 & 0.10 \\
\hline Cash receipts per farm & & & $\begin{array}{c}0.49^{* * *} \\
(0.12)\end{array}$ & 96 & 0.60 \\
\hline \multicolumn{6}{|l|}{$\underline{\text { Manufacturing outcomes }}$} \\
\hline Employment per establishment & $\begin{array}{c}8.35^{* * *} \\
(2.67)\end{array}$ & $\begin{array}{c}-4.71 * * \\
(2.08)\end{array}$ & $\begin{array}{c}5.44 * * * \\
(2.30)\end{array}$ & 672 & 0.48 \\
\hline $\begin{array}{l}\text { Log of real annual wage earnings } \\
\text { per worker }\end{array}$ & $\begin{array}{c}0.051 \\
(0.033)\end{array}$ & $\begin{array}{c}-0.056^{*} \\
(0.030)\end{array}$ & $\begin{array}{c}0.030^{* *} \\
(0.015)\end{array}$ & 672 & 0.99 \\
\hline Value added per capita & $\begin{array}{c}0.025^{* * *} \\
(0.007)\end{array}$ & $\begin{array}{c}-0.049^{* * *} \\
(0.010)\end{array}$ & $\begin{array}{c}0.027 * * * \\
(0.009)\end{array}$ & 672 & 0.50 \\
\hline \multicolumn{6}{|l|}{ Human capital outcomes ${ }^{(1)}$} \\
\hline $\begin{array}{l}\text { percent male age } 10-15 \text { working } \\
\text { and not in school }\end{array}$ & $\begin{array}{c}0.013 * * * \\
(0.004)\end{array}$ & $\begin{array}{c}-0.002 * * \\
(8.28 \mathrm{e}-04)\end{array}$ & $\begin{array}{c}-0.013 * * * \\
(0.005)\end{array}$ & 240 & 0.61 \\
\hline $\begin{array}{l}\text { percent female age } 10-15 \\
\text { working and not in school }\end{array}$ & $\begin{array}{c}0.005 \\
(0.003)\end{array}$ & $\begin{array}{c}-0.001^{*} \\
(6.70 \mathrm{e}-04)\end{array}$ & $\begin{array}{l}-0.005 \\
(0.004)\end{array}$ & 240 & 0.37 \\
\hline
\end{tabular}

Notes: Regressions are weighted using state population, include state and year fixed effects, and are clustered at the state level. Nominal values are deflated using the wholesale price index, base 1947-1949. (1) Because data are only available from the census and because of the nature of the outcome, child labor regressions use number of years regulations have been in place in each decade rather than the dummies. Robust standard errors in parenthesis. * significant at 10 percent; ** significant at 5 percent; $* * *$ significant at 1 percent 
Table 5: Fixed Effects Results with National Bank Controls, 1930 and Earlier

\begin{tabular}{|c|c|c|c|c|c|}
\hline & $\begin{array}{c}\begin{array}{c}\text { Deposit Insurance } \\
\text { before } 1920\end{array} \\
\end{array}$ & $\begin{array}{c}\text { Deposit Insurance } \\
\text { after } 1920\end{array}$ & "Branching & $\begin{array}{c}\begin{array}{c}\text { Number of } \\
\text { observations }\end{array} \\
\end{array}$ & $\begin{array}{l}\text { Within- } \\
\text { state } \mathrm{R}^{2}\end{array}$ \\
\hline \multicolumn{6}{|l|}{ Bank outcomes } \\
\hline Growth of national bank loans & $\begin{array}{l}-0.003 \\
(0.008)\end{array}$ & $\begin{array}{l}-0.020 \\
(0.016)\end{array}$ & $\begin{array}{c}0.007 \\
(0.010)\end{array}$ & 1488 & 0.59 \\
\hline Growth of state bank loans & $\begin{array}{l}0.029^{*} \\
(0.016)\end{array}$ & $\begin{array}{c}-0.14 * * * \\
(0.026)\end{array}$ & $\begin{array}{c}0.031 * * * \\
(0.010)\end{array}$ & 1488 & 0.62 \\
\hline \multicolumn{6}{|l|}{ Agricultural outcomes } \\
\hline Log number of farms & $\begin{array}{l}-0.006 \\
(0.050)\end{array}$ & $\begin{array}{c}0.051 \\
(0.053)\end{array}$ & $\begin{array}{c}-0.12 * * * \\
(0.024)\end{array}$ & 240 & 0.34 \\
\hline Log acres agricultural land & $\begin{array}{l}-0.051^{*} \\
(0.030)\end{array}$ & $\begin{array}{c}0.085^{* *} \\
(0.036)\end{array}$ & $\begin{array}{c}-0.12 * * * \\
(0.024)\end{array}$ & 240 & 0.18 \\
\hline Value of machines per acre & $\begin{array}{l}748 * * * \\
(287)\end{array}$ & $\begin{array}{l}-708 * * * \\
(275)\end{array}$ & $\begin{array}{c}562 \\
(567)\end{array}$ & 240 & 0.63 \\
\hline Value of crops per farm & $\begin{array}{l}-2.27 \mathrm{E}-04 \\
(1.55 \mathrm{E}-04)\end{array}$ & $\begin{array}{l}-1.51 \mathrm{E}-04 \\
(3.12 \mathrm{E}-04)\end{array}$ & $\begin{array}{c}1.26 \mathrm{E}-04 \\
(1.68 \mathrm{E}-04)\end{array}$ & 189 & 0.15 \\
\hline Cash receipts per farm & & & $\begin{array}{c}0.37 * * * \\
(0.15)\end{array}$ & 96 & 0.28 \\
\hline \multicolumn{6}{|l|}{ Manufacturing outcomes } \\
\hline Employment per establishment & $\begin{array}{c}2.38 \\
(2.28)\end{array}$ & $\begin{array}{l}-4.90^{* *} \\
(2.23)\end{array}$ & $\begin{array}{c}6.26^{* * *} \\
(1.73)\end{array}$ & 432 & 0.53 \\
\hline $\begin{array}{l}\text { Log of real annual wage earnings } \\
\text { per worker }\end{array}$ & $\begin{array}{l}-0.004 \\
(0.016)\end{array}$ & $\begin{array}{l}-0.060^{*} \\
(0.034)\end{array}$ & $\begin{array}{c}0.044 * * * \\
(0.018)\end{array}$ & 432 & 0.99 \\
\hline Value added per capita & $\begin{array}{l}0.019 * \\
(0.011)\end{array}$ & $\begin{array}{c}-0.050 * * * \\
(0.011)\end{array}$ & $\begin{array}{c}0.026^{* *} \\
(0.013)\end{array}$ & 432 & 0.56 \\
\hline \multicolumn{6}{|l|}{ Human capital outcomes $^{(1)}$} \\
\hline $\begin{array}{l}\text { percent male age } 10-15 \text { working } \\
\text { and not in school }\end{array}$ & $\begin{array}{l}-0.014 \\
(0.011)\end{array}$ & $\begin{array}{l}0.014^{*} \\
(0.008)\end{array}$ & $\begin{array}{c}-0.002 * * \\
(0.001)\end{array}$ & 192 & 0.62 \\
\hline $\begin{array}{l}\text { percent female age } 10-15 \\
\text { working and not in school }\end{array}$ & $\begin{array}{l}-0.001 \\
(0.008)\end{array}$ & $\begin{array}{c}0.002 \\
(0.005)\end{array}$ & $\begin{array}{c}-0.001 \\
(8.57 \mathrm{E}-04)\end{array}$ & 192 & 0.34 \\
\hline
\end{tabular}

Notes: Regressions are weighted using state population, and are clustered at the state level. Nominal values are deflated using the wholesale price index, base 1947-1949. Specifications include state and year fixed effects, and control for the growth of national bank assets.

(1) Because data are only available from the census and because of the nature of the outcome, child labor regressions use number of years regulations have been in place in each decade rather than the dummies. Robust standard errors in parenthesis. * significant at 10 percent; ** significant at 5 percent; $* * *$ significant at 1 percent 
Table 6: Fixed Effects Results with Time-Varying Controls

\begin{tabular}{|c|c|c|c|c|c|}
\hline & $\begin{array}{c}\begin{array}{c}\text { Deposit Insurance } \\
\text { before } 1920\end{array} \\
\end{array}$ & $\begin{array}{c}\text { Deposit Insurance } \\
\text { after } 1920\end{array}$ & Branching & $\begin{array}{l}\text { Number of } \\
\text { observations }\end{array}$ & $\begin{array}{l}\text { Within- } \\
\text { state } R^{2}\end{array}$ \\
\hline \multicolumn{6}{|l|}{ Bank outcomes } \\
\hline Growth of state bank loans & $\begin{array}{c}0.009 \\
(0.012)\end{array}$ & $\begin{array}{c}-0.11 * * * \\
(0.022)\end{array}$ & $\begin{array}{l}0.018 * * \\
(0.010)\end{array}$ & 1968 & 0.57 \\
\hline \multicolumn{6}{|l|}{$\underline{\text { Agricultural outcomes }}$} \\
\hline Log number of farms & $\begin{array}{c}0.017 \\
(0.078)\end{array}$ & $\begin{array}{c}0.071 \\
(0.074)\end{array}$ & $\begin{array}{c}-0.057 * * \\
(0.025)\end{array}$ & 336 & 0.41 \\
\hline Log acres agricultural land & $\begin{array}{l}-0.032 \\
(0.061)\end{array}$ & $\begin{array}{c}0.053 \\
(0.045)\end{array}$ & $\begin{array}{c}-0.048^{* *} \\
(0.021)\end{array}$ & 336 & 0.32 \\
\hline Value of machines per acre & $\begin{array}{c}1418^{* * *} \\
(455)\end{array}$ & $\begin{array}{l}-1249 * * * \\
\quad(327)\end{array}$ & $\begin{array}{c}762 \\
(529)\end{array}$ & 288 & 0.70 \\
\hline Value of crops per farm & $\begin{array}{l}-4.24 \mathrm{e}-04^{*} \\
(2.41 \mathrm{e}-04)\end{array}$ & $\begin{array}{l}-8.73 e-05 \\
(3.27 e-04)\end{array}$ & $\begin{array}{l}-1.20 \mathrm{e}-05 \\
(9.55 \mathrm{e}-05)\end{array}$ & 237 & 0.29 \\
\hline Cash receipts per farm & & & $\begin{array}{c}0.64 * * * \\
(0.26)\end{array}$ & 96 & 0.66 \\
\hline \multicolumn{6}{|l|}{$\underline{\text { Manufacturing outcomes }}$} \\
\hline $\begin{array}{l}\text { Employment per } \\
\text { establishment }{ }^{(1)}\end{array}$ & $\begin{array}{l}8.50 * * * \\
(2.72)\end{array}$ & $\begin{array}{c}-5.20 * * * \\
(2.06)\end{array}$ & $\begin{array}{l}4.29 * * \\
(2.06)\end{array}$ & 672 & 0.48 \\
\hline $\begin{array}{l}\text { Log of real annual wage } \\
\text { earnings per worker }\end{array}$ & $\begin{array}{l}-0.010 \\
(0.040)\end{array}$ & $\begin{array}{l}-0.017 \\
(0.033)\end{array}$ & $\begin{array}{l}0.020^{*} \\
(0.012)\end{array}$ & 672 & 0.99 \\
\hline Value added per capita & $\begin{array}{c}0.013 \\
(0.010)\end{array}$ & $\begin{array}{c}-0.036^{* * *} \\
(0.010)\end{array}$ & $\begin{array}{l}0.018 * * \\
(0.008)\end{array}$ & 672 & 0.67 \\
\hline \multicolumn{6}{|l|}{ Human capital outcomes $^{(2)}$} \\
\hline $\begin{array}{l}\text { percent male age } 10-15 \text { working } \\
\text { and not in school }\end{array}$ & $\begin{array}{l}-0.008 \\
(0.007)\end{array}$ & $\begin{array}{c}0.008 \\
(0.006)\end{array}$ & $\begin{array}{c}-0.001 * \\
(7.81 \mathrm{e}-04)\end{array}$ & 240 & 0.65 \\
\hline $\begin{array}{l}\text { percent female age } 10-15 \\
\text { working and not in school }\end{array}$ & $\begin{array}{l}-0.006 \\
(0.005)\end{array}$ & $\begin{array}{c}0.006 \\
(0.004)\end{array}$ & $\begin{array}{c}-0.001 * \\
(6.35 \mathrm{e}-04)\end{array}$ & 240 & 0.42 \\
\hline
\end{tabular}

Notes: Regressions are weighted using state population, and are clustered at the state level. Nominal values are deflated using the wholesale price index, base 1947-1949. Robust standard errors in parenthesis. * significant at 10 percent; ** significant at 5 percent; *** significant at 1 percent Specifications include state and year fixed effects, and control for the growth of national bank assets, deposits per state bank, an indicator for credit contractions, the proportion of state banks within a state, lagged growth of value added per firm, and lagged employment per firm.

(1) For employment per establishment, we use the same controls except lagged employment per firm.

(2) Because data are only available from the census and because of the nature of the outcome, child labor regressions use number of years regulations have been in place in each decade rather than the dummies. 
Table 7: Effect of banking laws on the annual growth rate of state-level personal income

\begin{tabular}{lc}
\hline \hline Dependent variable: & Growth rate \\
\hline Deposit Insurance & $-0.160^{* * *}$ \\
& $(0.0386)$ \\
Branching & $0.0628^{* * *}$ \\
& $(0.0239)$ \\
State and year fixed & \\
effects & Yes \\
Mean and standard & 0.041 \\
deviation of & $(0.226)$ \\
dependent variable & \\
& \\
Observations & 624 \\
R-squared & 0.59 \\
\hline
\end{tabular}

Notes: Regressions are weighted using state population, and are clustered at the state level. Nominal values are deflated using the wholesale price index, base 1947-1949. Robust standard errors are in parenthesis.

Annual growth rates are available for the years 1920,1921, and 1930-1940. These are calculated using personal income estimates, for data sources, see data Appendix.

* Significant at 10 percent; ${ }^{* *}$ significant at 5 percent; *** significant at 1 percent 